\title{
COMMENTS
}

\section{JUDICIAL REVIEW OF ANTITAKEOVER DEVICES EMPLOYED IN THE NONCOERCIVE TENDER OFFER CONTEXT: MAKING SENSE OF THE UNOCAL TEST}

\author{
GREgG H. KaNTER $†$
}

\begin{abstract}
When ... battles for corporate dominance spawn legal controversies, the judicial role is neither to displace the judgment of the participants nor to predetermine the outcome. Rather, the responsibility of the Court is to insure that rules designed to safeguard the faimess of the takeover process be enforced. ${ }^{1}$
\end{abstract}

Under Delaware law, ${ }^{2}$ the board of directors' role in a hostile tender offer has changed dramatically in recent years. A hostile tender offer ${ }^{3}$ is a takeover mechanism by which the tender offeror seeks to acquire a controlling interest in the target corporation. ${ }^{4}$ Since a tender offer is addressed directly to individual shareholders without securing the approval of the target corporation's board, ${ }^{5}$ the directors were traditionally almost powerless against this type of takeover attempt. Under the Delaware General Corporation Law ${ }^{6}$ and the Securities Exchange Act of $1934,{ }^{7}$ the only function of the

† B.A. 1985, J.D. Candidate 1990, University of Pennsylvania.

I Norlin Corp. v. Rooney, Pace Inc., 744 F.2d 255, 258 (2d Cir. 1984).

2 This paper's discussion will be limited to Delaware corporate law, which is considered the most influential in the country. See Dynamics Corp. of Am. v. CTS Corp., 805 F.2d 705, 708 (7th Cir. 1986); Gilson \& Kraakman, Delaware's Intermediate Standard for Defensive Tactics: Is There Substance to Proportionality Review?, 44 Bus. LAw. 247, 248 (1989) (stating that Delaware corporate law governs "the largest proportion of the largest business transactions in history"); Labaton, Judge Is Focus of Time Inc. Contest, N.Y. Times, June 26, 1989, at D1, col. 3 ("In corporate law, Delaware, the home of more major companies than any other state, has become more influential than the United States Supreme Court.").

3 A tender offer is "generally defined as a public invitation addressed to all shareholders of a corporation to tender their shares for a specified price within a limited period of time." Andre, Tender Offers for Corporate Control: A Critical Analysis and Proposals for Reform, 12 DEL. J. CoRP. L. 865, 866 n.l (1987).

4 See Kreider, Corporate Takeovers and the Business Judgment Rule: An Update, Corp. Prac. Commentator 119, 120 (1988). A controlling interest in a corporation is the ownership of a sufficient number of voting shares to dictate corporate action.

5 See id.

6 Del. Code ANN. tit. 8, §§ 1-398 (1983 \& Supp. 1988).

715 U.S.C. $\S 78$ (1982, Supp. IV 1986 \& Supp. V 1987). 
target directors in the process is giving an opinion concerning the tender offer. ${ }^{8}$ With the advent and judicial sanctioning of antitakeover devices to prevent unsolicited tender offers, however, the target board has taken a more prominent role in the tender offer process. ${ }^{9}$ The ability to enact an antitakeover device, or redeem an existing one, has granted the target board a virtual veto power over tender offers. ${ }^{10}$

This assumption of power in the tender offer context creates an inherent conflict of interest for the target's directors. " duty of directors to the shareholders requires the maximization of

8 SEC Rule 14e-2, issued under the Securities Exchange Act of 1934, requires the target board to recommend acceptance or rejection of the tender offer, to express neutrality towards the offer, or to state reasons for an inability to take a position on the offer, within 10 days after the commencement of the offer. This opinion, however, is used merely to assist the shareholders in their evaluation of the tender offer and has no binding effect. See 17 C.F.R. $\S 240.14 \mathrm{e}-2$ (1988).

Under the Delaware General Corporation Law, the target board's impotence in tender offers sharply contrasts with the board's role in other transactions involving a transfer of corporate control. See TW Servs., Inc. v. SWT Acquisition Corp., [Current] Fed. Sec. L. Rep. (CCH) \ 94,334, at 92,181 (Del. Ch. Mar. 2, 1989); cf. Del. Code ANN. tit. 8, §§ 251, 253 (1983 \& Supp. 1988) (requiring board approval in a merger or consolidation); $i d$. at $\$ 271$ (requiring board approval in a sale of substantially all of the corporation's assets); id. at $\S 275$ (requiring board approval for dissolution).

9 See CRTF Corp. v. Federated Dep't Stores, 683 F. Supp. 422, 437, 440 (S.D.N.Y. 1988); Unocal Corp. v. Mesa Petroleum Co., 493 A.2d 946, 957 (Del. 1985); TW Servs., [Current] Fed. Sec. L. Rep. (CCH) at 92,181; Andre, supra note 3, at 868-69; Bebchuk, The Pressure to Tender: An Analysis and a Proposed Remedy, 12 Del. J. CoRP. L. 911,947 (1987); Matheson \& Norberg, Hostile Share Acquisitions and Corporate Governance: A Framework for Evaluating Antitakeover Activities, 47 U. PrTT. L. Rev. 407, 409 (1986); Note, Poison Pill Rights: Toward a Two-Step Analysis of Directors' Fidelity to Their Fiduciary Duties, 56 Geo. WAsh. L. Rev. 373, 373 (1988).

It appears that the use of antitakeover devices will continue to be governed by the courts because the Securities and Exchange Commission is unlikely to impose regulations on the use of antitakeover devices. See Matheson \& Norberg, supra, at 426-35.

10 See MAI Basic Four, Inc. v. Prime Computer, Inc., [1988-1989 Transfer Binder] Fed. Sec. L. Rep. (CCH) I 94,179, at 91,634 (Del. Ch. Dec. 20, 1988); Andre, supra note 3, at 886-87; Matheson \& Norberg, supra note 9, at 475 .

The target's directors have a veto power over a tender offer because it is generally within their power to redeem the antitakeover device. See Moran v. Household Int'l, 490 A.2d 1059, 1083 (Del. Ch.), aff'd, 500 A.2d 1346 (Del. 1985); Matheson \& Norberg, supra note 9, at 475; Oesterle, The Negotiation Model of Tender Offer Defenses and the Delaware Supreme Court, 72 CoRnell L. Rev. 117, 120-21 (1986); Note, supra note 9 , at 379-80.

An antitakeover device which is not redeemable by the board of directors would be enjoined by a court. See Doskocil Co. v. Griggy, No. 10,095, slip op. at 4, 7 (Del. Ch. Aug. 4, 1988).

11 See Andre, supra note 3, at 889; Easterbrook \& Fischel, The Proper Role of a Target's Management in Responding to a Tender Offer, 94 HARv. L. REv. 1161, 1175 (1981); 
the value of their stock. ${ }^{12}$ This duty may compel the board to redeem the antitakeover device and provide the shareholders with the opportunity to tender their shares. ${ }^{13}$ The surrender of corporate control, however, may be detrimental to the directors' personal and economic interests. ${ }^{14}$ The Delaware Supreme Court addressed this conflict of interest in Unocal Corp. $v$. Mesa Petroleum Co. ${ }^{15}$ by adopting an intermediate standard of judicial review for directors' actions in the tender offer context. ${ }^{16}$ Unocal upholds the use of an antitakeover device where the directors demonstrate "reasonable grounds for believing that a danger to corporate policy and effectiveness existed"17 and the defensive measure is "reasonable in relation to the threat posed." 18

The Unocal test has been employed in numerous instances to judge the validity of antitakeover devices. Yet a consistent judicial model of the circumstances under which target directors may block a tender offer based solely on the belief that the tender price is less than their estimated value of the corporation has not emerged. The need for consistency is particularly important since opposition to hostile takeovers is typically based on price considerations. ${ }^{19}$ This Comment seeks to develop a coherent formulation of the Unocal test

Gilson \& Kraakman, supra note 2, at 247; Siegel, Tender Offer Defensive Tactics: A Proposal for Reform, 36 Hastings L.J. 377, 382 (1985); Note, supra note 9, at 376-77.

12 See infra notes 61-67 \& 172 and accompanying text; $c f$. Revlon, Inc. v. MacAndrews \& Forbes Holdings, 506 A.2d 173, 182 (Del. 1986) ("[When] it became apparent ... that the break-up of the company was inevitable ... [t] the duty of the board . . . changed from the preservation of [the target] as a corporate entity to the maximization of the company's value at a sale for the stockholders' benefit. . . . [O]btaining the highest price for the benefit of the stockholders should have been the central theme guiding director action.").

13 See, e.g., City Capital Assocs. v. Interco, Inc., 551 A.2d 787, 798 (Del. Ch.) ("[T]here may come a time when a board's fiduciary duty will require it to redeem the [antitakeover device] and to permit the shareholders to choose [whether or not to tender their shares]."), appeal dismissed, 556 A.2d 1070 (Del. 1988); see also Matheson \& Norberg, supra note 9 , at 453 ("The board is still bound to act in the shareholders' and the corporation's best interest in pursuing possible alternative courses of action, even where one alternative is a possible change of control.").

14 See infra notes 85-88 and accompanying text.

15493 A.2d 946 (Del. 1985).

16 See infra note 100 (explaining why Unocal is an intermediate standard of review). Since its pronouncement, Unocal's intermediate test has been widely accepted as Delaware's standard of judicial review for antitakeover actions. See Stevenson, The Unocal Standard's Application in Delaware, NAT'L L.J., Nov. 14, 1988, at 22, col. 3. As of the August, 1989 Annual Cumulative Supplement, SHEPards CrTations reported 104 references to the Unocal opinion.

17 Unocal, 493 A.2d at 955.

18 Id.

19 See infra notes 53-60 and accompanying text. 
that is both consistent with the Unocal opinion's underlying principles and reflective of the economic realities facing the target directors.

In Part I, this Comment will develop a prototypical model of a noncoercive tender offer to serve as a foundation for the analysis of the Unocal test. ${ }^{20}$ This model will help illustrate how a noncoercive tender offer is obstructed by an antitakeover device. Economic justifications for the use of the antitakeover device will be examined by discussing the directors' response to the tender offer.

In Part II, this Comment will discuss the fiduciary duties of a corporation's board of directors and the standards employed by the Delaware courts to determine compliance with these duties. This Part concludes that the standards of judicial review prior to Unocalthe business judgment rule ${ }^{21}$ and the intrinsic fairness test ${ }^{22}$-are inappropriate given the directors' conflict of interest in the tender offer context. As a result, there exists a need for an intermediate standard of judicial review such as that enunciated in Unocal.

In Part III, this Comment will explore the application of the Unocal test to the noncoercive tender offer model. An examination of recent case law ${ }^{23}$ indicates that courts have not applied the Unocal

20 A non-coercive tender offer may be defined as a tender offer whose structure does not affect the shareholders' ability to rationally evaluate its terms. See Bebchuk, supra note 9, at 911-13. This is to be contrasted with a coercive tender offer which is structured to "render mandatory in substance that which is voluntary in form." City Capital Assocs. v. Interco, Inc., 551 A.2d 787, 797 (Del. Ch.), appeal dismissed, 556 A.2d 1070 (Del. 1988). An example of the prototypical coercive structure is a frontloaded, two-tiered tender offer. The terms of this tender offer provide that shareholders who subscribe to the tender will receive the tender offer price, and those who do not tender will be squeezed-out in a back-end merger at a lower price. Since there is a substantial difference in the consideration received, shareholders may be compelled to tender their shares even if they believe that the tender price is inadequate.

In contrast, an example of a non-coercive structure is one where the consideration given to non-tendering shareholders in a back-end merger is generally equal to the tender offer price. Consequently, since the shareholders do not fear being squeezed out in the second step merger at a lower price, there is no inherent coercion to tender. See Gilson \& Kraakman, supra note 2, at 254.

21 See infra notes 68-78 and accompanying text.

22 See infra notes 79-84 and accompanying text.

23 See, e.g., Dynamics Corp. of Am. v. CTS Corp., 805 F.2d 705 (7th Cir. 1986); Southdown, Inc. v. Moore McCormack Resources, 686 F. Supp. 595 (S.D. Tex. 1988); BNS, Inc. v. Koppers Co., 683 F. Supp. 458 (D. Del. 1988); CRTF Corp. v. Federated Dep't Stores, 683 F. Supp. 422 (S.D.N.Y. 1988); Samjens Partners I v. Burlington Indus., 663 F. Supp. 614 (S.D.N.Y. 1987); Mills Acquisition Co. v. MacMillan, Inc., [Current] Fed. Sec. L. Rep. (CCH) I 94,401 (Del. May 3, 1989); Ivanhoe Partners v. Newmont Mining Corp., 535 A.2d 1334 (Del. 1987); Polk v. Good, 507 A.2d 531 (Del. 1986); Revlon, Inc. v. MacAndrews \& Forbes Holdings, 
test in a uniform manner; the nominal elements of the test have produced divergent substantive analyses resulting in inconsistent outcomes. ${ }^{24}$ These different applications of the Unocal test are a consequence of the test's ambiguous language, which has been interpreted differently by the lower courts. ${ }^{25}$

Finally, in Part IV, this Comment will propose a reformulation of the Unocal test which will rectify its present interpretational dilemma. In particular, this Comment suggests that courts resolve Unocal's ambiguities by reference to two principles underlying the Unocal opinion: that directors should act in the shareholders' best interest, and that courts should employ an intermediate standard of review in the tender offer context. While these principles indicate the appropriate interpretation for the first component of the Unocal test, they also demonstrate that all of the existing formulations of Unocal's second component are inadequate. Therefore, this Comment proposes a new version of the test that is compatible with Uno-

506 A.2d 173 (Del. 1986); Moran v. Household Int'l, 500 A.2d 1346 (Del. 1985); Paramount Communications v. Time, Inc., [Current] Fed. Sec. L. Rep. (CCH) If 94,514 (Del. Ch. July 14, 1989), aff'd sub nom. Literary Partners v. Time, Inc., (Del. July 24, 1989) (available on LEXIS and WESTLAW); TW Servs., Inc. v. SWT Acquisition Corp., [Current Decisions Transfer Binder] Fed. Sec. L. Rep. (CCH) I 94,334 (Del. Ch. Mar. 2, 1989); In re RJR Nabisco, Inc. Shareholders Litig., [19881989 Transfer Binder] Fed. Sec. L. Rep. (CCH) I 94, 194 (Del. Ch. Jan. 31, 1989); In $r e$ Holly Farms Corp. Shareholders Litig., [1988-1989 Transfer Binder] Fed. Sec. L. Rep. (CCH) I 94,181 (Del. Ch. Dec. 30, 1988); MAI Basic Four, Inc. v. Prime Computer, [1988-1989 Transfer Binder] Fed. Sec. L. Rep. (CCH) ף 94,179 (Del. Ch. Dec. 20, 1988); Grand Metro. PLC v. Pillsbury Co., 558 A.2d 1049 (Del. Ch. 1988); City Capital Assocs. v. Interco, Inc., 551 A.2d 787 (Del. Ch.), appeal dismissed, 556 A.2d 1070 (Del. 1988); Nomad Acquisition Corp. v. Damon Corp., [1988-1989 Transfer Binder] Fed. Sec. L. Rep. (CCH) I 94,040 (Del. Ch. Sept. 16, 1988); In re Fort Howard Shareholders Litig., No. 9991 (Del. Ch. Aug. 8, 1988); Doskocil Co. v. Griggy, No. 10,095 (Del. Ch. Aug. 4, 1988); Robert M. Bass Group v. Evans, 552 A.2d 1227 (Del. Ch.), appeal dismissed sub nom. MacMillan, Inc. v. Robert M. Bass Group, 548 A.2d 498 (Del. 1988); Tate \& Lyle PLC v. Staley Continental, [1987-1988 Transfer Binder] Fed. Sec. L. Rep. (CCH) I 93,764 (Del. Ch. May 9, 1988); Facet Enter. v. Prospect Group, No. 9746 (Del. Ch. Apr. 15, 1988); West Point-Pepperell, Inc. v. J.P. Stevens \& Co., 542 A.2d 770 (Del. Ch. 1988); AC Acquisitions v. Anderson, Clayton \& Co., 519 A.2d 103 (Del. Ch. 1986); MacAndrews \& Forbes Holdings v. Revlon, 501 A.2d 1239, 1250 (Del. Ch. 1985), aff'd, 506 A.2d 173 (Del. 1986).

24 See supra note 23 (noting cases in which the Unocal test has been applied in a myriad of ways); see also Oesterle, supra note 10, at 118 (noting that in the wake of Unocal, courts must develop a "sophisticated theory" for determining when tender offer defenses serve a corporation's best interests, and that this development has created concern among the officers of Delaware corporations).

25 See infra notes 115-17 \& 154-70 and accompanying text (describing the different applications by courts of the Unocal test resulting from the ambiguity of its language). 
cal's underlying policies. Under the proposed test, an antitakeover device is presumed reasonable for a two-month period following a tender offer if the directors present any evidence that it may maximize shareholder wealth. Thereafter, the antitakeover device is presumed reasonable only if the directors demonstrate that there is a substantial probability of maximizing shareholder wealth through negotiations with the tender offeror. If the directors are able to satisfy this second prong, they will have a duty to engage in good faith negotiations with the tender offeror to maximize shareholder wealth through a merger.

\section{The Noncoercive Tender Offer Model}

This Comment shall examine the application of the Unocal test to the following prototype of a noncoercive tender offer. ${ }^{26}$ The target is a publicly held corporation with an established market for its stock. ${ }^{27}$ An antitakeover device enables the target in effect to defeat any unsolicited tender offer not approved by its board. ${ }^{28}$ The tender

26 This Comment shall limit its analysis of the Unocal test to noncoercive tender offers. Since coercive tender offers prevent shareholders from making a rational choice as to whether to tender their shares, see supra note 20 , the directors have a legitimate reason for maintaining the antitakeover device. See Ivanhoe Partners, 535 A.2d at 1342; Unocal Corp. v. Mesa Petroleum Co., 493 A.2d 946, 956 (Del. 1985); Kreider, supra note 4 , at 136 . This Comment focuses on the price considerations between the tender price and the probability that the directors can achieve a more valuable alternative, so concerns over the structure of the tender offer are not relevant. Moreover, an analysis of noncoercive tender offers may be more relevant to the present takeover climate since many companies have adopted "fair price" provisions in their charters which effectively require the tender offer to be noncoercive. See Bebchuk, supra note 9, at 942; Gilson \& Kraakman, supra note 2, at 254 n.29; Smith, Fair Price and Redemption Rights: New Dimensions in Defense Charter Provisions, 4 DeL. J. CoRP. L. 1, 12 (1978).

27 The Delaware General Corporation Law generally assumes the existence of an established market where the corporation's stock is either listed on a national exchange or held by more than 2,000 shareholders. See Del. Code AnN. tit. 8, \$ 262(b) (1983 \& Supp. 1988) (granting appraisal rights to the dissenting shareholders of a corporation merged into another corporation only if the consideration received is stock in a corporation that is neither listed on a national securities exchange nor held by more than 2,000 shareholders).

28 See Kreider, supra note 4, at 125 ("In recent years, many corporations have adopted antitakeover devices ...."); Matheson \& Norberg, supra note 9, at 412 ("200 of Standard \& Poor's 500 largest corporations now have some form of antitakeover provisions.").

It is largely irrelevant whether the antitakeover device is enacted in direct response to the tender offer or was already in place. In either case, the directors are making the same essential decision to oppose the takeover bid, albeit by actively adopting a defensive measure or by passively maintaining an existing one. Hence

[w] hen the [target] board of directors is faced with a tender offer and a 
offeror commences an all cash tender offer for all shares of the target at a premium above the market price ${ }^{29}$ and commits itself to engage in an immediate takeout if the tender is successful. ${ }^{30}$ The tender offer, however, is made contingent upon the target's redemption of its antitakeover device. ${ }^{31}$

request to redeem the [defensive measure] ... [t] $]$ hey will be held to the same fiduciary standards any other board of directors would be held to in deciding to adopt a defensive mechanism, the same standard . . . they were held to in originally approving the [defensive measure].

Moran v. Household Int'l, 500 A.2d 1346, 1354 (Del. 1985) (citing Unocal, 493 A.2d at $954-55,958)$. The only notable difference in analysis of prospective versus retrospective implementation of an antitakeover device is that courts are less likely to find a lack of reasonable investigation where the board adopts a defensive measure prior to the takeover bid, presumably because the directors made their decision less hastily. See Johnson \& Siegel, Corporate Mergers: Redefining the Role of Target Directors, $136 \mathrm{U}$. PA. L. Rev. 315, 336-37 (1987); Veasey \& Mongan, Fiduciary Duties of Directors in Control Contesis, in Hostile Battles for Corporate Control 1988, at 449, 504-05 (citing Edelman v. Phillips Petroleum Co., No. 7899, slip op. at 8 (Del. Ch. Feb. 12, 1985)); Veasey, The New Incarnation of the Business Judgment Rule in Takeover Defenses, 11 DEL. J. CORP. L. 503, 508 (1986).

29 See, e.g., TW Servs., Inc. v. SWT Acquisition Corp., [Current] Fed. Sec. L. Rep. (CCH) If 94,334, at 92,179 n.7 (Del. Ch. Mar. 2, 1989) ("40\% and 50\% premiums over current stock price are typically encountered in hostile takeover situations."); Labaton, supra note 2, at Dl, col. 3 ("Recent years have seen an unparalleled number of takeovers in a climate that has encouraged multi-billiondollar bids, often significantly above where a target company's stock had been trading.").

30 An immediate takeout is a follow-up merger where the tender offeror acquires all of the non-tendering shares within a few months of the takeover. See Bebchuk, Toward Undistorted Choice and Equal Treatment in Corporate Takeovers, 98 Harv. L. REv. 1693, 1709 (1985). Since the prototype tender offer described in this Comment is noncoercive, the takeout price paid to minority shareholders will be substantially equal to that paid in the tender offer. See supra note 20 and accompanying text.

The tender offeror will be able to squeeze out the minority shareholders provided: 1) it has acquired a sufficient percentage of the target to satisfy the shareholder approval requirement for a merger (a mere majority of voting shares), see Del. Code ANN. tit. 8, § 251(c) (1983 \& Supp. 1988) (mandating shareholder approval for a merger), and 2) the follow-up merger complies with $\$ 203$ of the Delaware statute. See id. $\$ 203$ (Supp. 1988) (prohibiting certain business combinations between the corporation and an interested shareholder within three years of the shareholder's attainment of "interested" status).

The terms of this prototypical noncoercive tender offer (for any and all shares for cash with an immediate takeout provision) is the least coercive structure possible. See Gilson \& Kraakman, supra note 2, at 254 \& n.29; Stevenson, supra note 16, at 24.

31 Unsolicited tender offers are generally made contingent upon several conditions, one of which is the revocation of any antitakeover devices. See, e.g., TW Servs., [Current] Fed. Sec. L. Rep. (CCH) at 92,177 n.4 (listing conditions of SWT's tender offer, which include redemption of rights plan); Nomad Acquisition Corp. v. Damon Corp., [1988-1989 Transfer Binder] Fed. Sec. L. Rep. (CCH) I 94,040, at 90,870 (Del. Ch. Sept. 16, 1988) (listing conditions of Nomad's offer, which include 
Typically, if the target's board wished to defeat the tender offer, it would proceed in the following manner. ${ }^{32}$ First, if a majority of the current board was not independent, the board would appoint a special committee composed primarily of outside directors in order to respond to the tender offer. ${ }^{33}$ The group of independent directors would then consult with an investment banker ${ }^{34}$ to determine

redemption of rights plan); City Capital Assocs. v. Interco, Inc., 551 A.2d 787, 792 (Del. Ch.) (listing conditions of City Capital's tender offer, which include redemption of rights plan), appeal dismissed, 556 A.2d 1070 (Del. 1988). The prototypical tender offer in this Comment, however, is not contingent upon any conditions other than the tender offer's success (that is, the tendering of the desired percentage of outstanding shares by the shareholders).

32 See generally Streeter, Memo to the Board of Directors Re: Obligations in a Takeover Situation, 4 CoRp. Couns. Q., July 1988, at 55, 60-63 (describing the procedural posturing sufficient to demonstrate good faith and due care in defeating a takeover bid).

33 See Simpson, The Emerging Role of the Special Committee - Ensuring Business Judgment Rule Protection, 43 Bus. LAw. 665, 674 (1988); Veasey, supra note 28, at 51011. Outside directors do not hold lucrative management positions, so a majority of the special committee would have much less of a conflict of interest than would the full board. See Simpson, supra, at 666-67. The potential for directorial abuse is thus decreased.

Courts generally extend greater deference to the special committee's decision to use the antitakeover device. See Moran v. Household Int'l, 500 A.2d 1346, 1356 (Del. 1985) ("[Where] a majority of the board favoring the [antitakeover device] proposal consist[s] of outside independent directors ... [the proof of reasonableness is] materially enhanced . . . ."); West Point-Pepperell, Inc. v. J.P. Stevens \& Co., 542 A.2d 770, 780 (Del. Ch. 1988) ("[A] decision made by an independent board will not give rise to liability ... if it is made in good faith and the exercise of due care."); Anderson \& Bibi, Defensive Strategies: Recapitalization and Restructuring Transactions, in Hostile BaTtles for Corporate Control 1988, at 281, 288-89; Simpson, supra, at 667.

Some commentators, however, have questioned the "independence" of outside directors. See Panter v. Marshall Field \& Co., 646 F.2d 271, 300-01 (7th Cir.) (Cudahy, C.J., concurring in part and dissenting in part), cert. denied, 454 U.S. 1092 (1981); Mills Acquisition Co. v. MacMillan Inc., 559 A.2d 1261, 1271 (Del. 1989); M. Eisenberg, The Structure of the Corporation: A Legal Analysis 144-48 (1976); see also infra notes 86-88 and accompanying text (discussing outside directors' economic and noneconomic interests in defeating takeover bids).

The power to create a special committee which is vested with many of the powers of the full board of directors is expressly granted in the Delaware General Corporation Law. See Del. Code ANN. tit. 8, \& 141(c) (1983 \& Supp. 1988).

34 Consultation with an investment banker regarding the merits of a tender offer is virtually required by the directors' fiduciary duty of due care. See Streeter, supra note 32, at 61; Veasey, supra note 28 , at 510.

The credibility of investment bankers' studies has been the subject of controversy. See, e.g., Dynamics Corp. of Am. v. CTS Corp., 805 F.2d 705, 710-11 (7th $\mathrm{Cir}$. 1986) (noting that investment bankers might not be disinterested since their compensation may be contingent upon the obstruction of the hostile tender offer); Southdown Inc. v. Moore McCormack Resources, 686 F. Supp. 595, 603 (S.D. Tex. 1988) ("The opinion of Moore McCormack's investment advisor lacks support by 
whether the tender offer is in the shareholders' best interest. ${ }^{35} \mathrm{~A}$ tender offer at a premium over the market price will be in the shareholders' best interest if it represents the target's "full" value: the maximum value that the shareholders might be able to obtain. ${ }^{36}$ Any analysis of the target's "full" value is based upon an estimate of its potentiality: its possible yet unrealized value. These projections, however, are necessarily uncertain. ${ }^{37}$ Therefore, the directors' eval-

verifiable facts ... ."); Interco, 551 A.2d at 792 (stating that investment banker's "socalled reference ranges do not purport to be a range of fair value; but just what they purport to be is (deliberately, one imagines) rather unclear"); Veasey \& Mongan, supra note 28, at 471 ("In Kahn v. United States Sugar Corp., No. 7313 (Del. Ch. Dec. $10,1985)$, the court was critical of valuation opinions presented by each side's investment banker as to the fairness of a merger proposal."); Bartlett, Delaware Courts Get Tough Toward Investment Bankers, N.Y. Times, May 30, 1989, at D1, col. 1 ("Investment bankers are being sharply criticized in the Delaware courts . . . for giving arbitrary investment opinions about the value of bids. "The courts are suspicious and will no longer accept blindly the advice of bankers,' said Chancellor William T. Allen of the Delaware Chancery Court . ....").

35 See Matheson \& Norberg, supra note 9, at 448 ("[I]t may be part of management's duty to actively resist proposals that management does not consider to be in the best interests of the shareholders.").

36 See Interco, 551 A.2d at 797-98 ("Even where an offer is noncoercive, it may represent a 'threat' to shareholder interests in the special sense that an active negotiator with power, in effect, to refuse the proposal may be able to extract a higher or otherwise more valuable proposal, or may be able to arrange an alternative transaction or a modified business plan that will present a more valuable option to shareholders."); AC Acquisitions v. Anderson, Clayton \& Co., 519 A.2d 103, 112 (Del. Ch. 1986) (stating that a tender offer at a "fair" price might not be in shareholders' best interest if they prefer an alternative developed by the directors).

The central assumption of this view is that the market does not efficiently price the value of a corporation's stock. See, e.g., Dynamics, 805 F.2d at 717 ("II]t can be argued that the value fixed by the market is the value of the marginal share rather than the sale value of the entire company as a unit."); Paramount Communications v. Time, Inc., [Current] Fed. Sec. L. Rep. (CCH) I 94,514, at 93,277 (Del. Ch. July 14, 1989) ("But just as the Constitution does not enshrine Mr. Herbert Spencer's social statics, neither does the common law of director's duties elevate the single theory of a single, efficient capital market to the dignity of a sacred text."), aff'd sub nom. Literary Partners v. Time, Inc., (Del. July 24, 1989) (available on LEXIS and WESTLAW); see also Andre, supra note 3, at 871 ("Proponents of the view that the stock market is not efficient and that certain stocks are undervalued argue that tender offers merely exploit underpriced stock."); Lipton, Corporate Governance in the Age of Finance Corporatism, 136 U. PA. L. REv. 1, 32 (1987) (noting "the failure of the financial markets to place a value on the securities of companies that is commensurate with their underlying assets'); Oesterle, supra note 10, at 124-26 (noting that even if the market prices a company's stock efficiently, its valuation is subject to error since the market price can only reflect public information while the managers may possess inside information). But see $\mathrm{T}$. Copeland \& J. Weston, Financial Theory and Corporate Policy 361-94 (3d ed. 1988) (discussing the results of empirical research that, to varying degrees, supports the efficient market hypothesis under certain circumstances).

37 See Fabrikant, Is Paramount Ripe for a Takeover?, N.Y. Times, June 9, 1989, at 
uation of the tender offer will focus on the probability that they can develop an alternative option more valuable than the tender price.

There are four basic options ${ }^{38}$ that may yield a greater value than the tender offer: undertaking an internal restructuring, ${ }^{39}$ engaging in a Revlon-style auction, ${ }^{40}$ waiting for a market adjustment, ${ }^{41}$ or negotiating directly with the tender offeror. ${ }^{42}$

An internal restructuring is a self-initiated reorganization of the financial structure of a corporation. The most common techniques are liquidations, ${ }^{43}$ spin-offs, ${ }^{44}$ and recapitalizations. ${ }^{45}$ If the invest-

D6, col. 3 (noting that investment bankers' projections of the true value of a corporation are "merely estimates"); supra note 34 (discussing the inaccuracy of some investment bankers' projections).

38 The four listed options are not an all-inclusive list of possible alternatives to the tender offer. Discussion of other possible options is not particularly relevant for this Comment's purposes because these other options essentially achieve the same result and are developed through similar means. The listed options are merely some of the more currently popular alternatives.

39 See Anderson \& Bibi, supra note 33, at 283; Rosenfeld, The Use of Management LBO's, Leveraged Transactions, and White Knight Strategies in Response to Hostile Takeovers, in Hostile BatTles for Corporate ConTrol 1988, at 11; see also Fabrikant, Adding Up What Time Might Be Worth, N.Y. Times, June 22, 1989, at D21, col. 4 ("Time's management has argued that in the long term it could realize and get better values [through a proposed merger with Warner Communication].").

40 See Dynamics, 805 F.2d at 710; Revlon, Inc. v. MacAndrews \& Forbes Holdings, 506 A.2d 173, 182 (Del. 1986); Gilson \& Kraakman, supra note 2, at 260.

41 See Interco, 551 A.2d 787, 793-94; Gilson \& Kraakman, supra note 2, at 260.

42 See, e.g., Yanow v. Scientific Leasing, Inc., [1987-1988 Transfer Binder] Fed. Sec. L. Rep. (CCH) I 93,660, at 98,031-32 (Del. Ch. Feb. 5, 1988) (target negotiates with hostile bidder); Gilbert v. El Paso Co., 490 A.2d 1050, 1053 (Del. Ch. 1984) (same); see also Gilson \& Kraakman, supra note 2, at 260 (noting negotiation with tender offeror as an alternative option).

43 See Lipton, supra note 36, at 33. A liquidation involves the sale of some or all of the target corporation's assets followed by a distribution of cash to the shareholders. See Rosenfeld, supra note 39, at 13-15.

44 A spin-off involves the creation of a new corporation (often a subsidiary) comprised of assets of the parent followed by a distribution to shareholders of the new company's stock. The effect is that shareholders subsequently own $100 \%$ of two independent companies, rather than the original one. This provides the shareholders with a combined distribution and equity value greater than the tender offer price. See Anderson \& Bibi, supra note 33, at 283, 297.

45 "Recapitalizations involve a reclassification and reallocation of the currently existing stock of a company. . . Typically, the public stockholders of the recapitalized company will receive a combination of cash, debt securities and equity (preferred and/or common stock) in the newly recapitalized company." Id. at 295; see also Lin Rejects $\$ 6.7$ Billion McCaw Bid, N.Y. Times, June 21, 1989, at D18, col. 4 (noting that Lin "was considering several options to enhance shareholder value, including a recapitalization and a special dividend for shareholders").

One of the more common uses of a recapitalization is to achieve a management led leveraged buy-out. Since this type of transaction, however, involves self-dealing, see Lederman, Representing a Public Company in a Leveraged Buyout Transaction, in 
ment banker's projected value of a restructuring plan is greater than the tender offer price, the directors may adopt the restructuring plan or use the estimated restructuring value as a tool in negotiating with the tender offeror.

A Revlon-style auction is the act of voluntarily putting the target corporation "on the block" with the expectation that competitive bidding will result in a sale price for the stockholders greater than the initial tender offer. ${ }^{46}$ Typically, the target's directors will solicit a "friendly" bidder, known as a "white knight," to compete with the tender offeror. ${ }^{47}$ If a competitive bidder materializes, the board assumes the role of auctioneer and encourages the bidding in order to obtain the highest price for its shareholders. ${ }^{48}$

Hostile Battles for Corporate Control 1988, at 110-12, it is reviewed under the intrinsic fairness test and is not directly addressed by this Comment.

46 See, e.g., Revlon, Inc. v. MacAndrews \& Forbes Holdings, 506 A.2d 173, 182 (Del. 1986) (stating that when the sale of a company becomes inevitable, it is the duty of the board of directors to maximize the sale price for the stockholders through the encouragement of competitive bids by all interested parties); Robert M. Bass Group v. Evans, 552 A.2d 1227, 1241 (Del. Ch.) (a noncoercive tender offer is a threat "only in the minimal sense that the [tender offer], although fair, is less than the highest price that the defendants' financial advisors believed might be obtained if the entire company were put up for sale"), appeal dismissed sub nom. MacMillan, Inc. v. Robert M. Bass Group, 548 A.2d 498 (Del. 1988); see also Bebchuk, supra note 9, at 929 ("[T] target's shareholders might expect that another bidder, who can put the target's assets to a more valuable use than can the present bidder, will come forward later with a higher offer."); Matheson \& Norberg, supra note 9, at 454 ("It is well recognized that creating an auction atmosphere may benefit the target shareholders.").

Technically speaking, a Revlon-style auction may be defined as a transaction which results in a change of corporate control. See Paramount Communications v. Time, Inc., [Current] Fed. Sec. L. Rep. (CCH) I 94,514, at 93,277 (Del. Ch. July 14, 1989), aff'd sub nom. Literary Partners v. Time, Inc., (Del. July 24, 1989) (available on LEXIS and WESTLAW). If a true auction occurs, it need not be conducted in any set manner. See Mills Acquisition Co. v. MacMillan, Inc., 559 A.2d 1261, 1286 (Del. 1989) ("Directors are not required by Delaware law to conduct an auction according to some standard formula, only that they observe the significant requirement of fairness for the purpose of enhancing general shareholder interests.").

47 See Tate \& Lyle v. Staley Continental, [1987-1988 Transfer Binder] Fed. Sec. L. Rep. (CCH) \ 93,764, at 98,587 (Del. Ch. May 9, 1988); Matheson \& Norberg, supra note 9 , at $454 \mathrm{n} .164$. The courts have permitted the target to bestow benefits upon potential or actual white knights provided that such benefits are reasonably calculated to enhance the bidding. See In re Holly Farms Corp. Shareholders Litig., [1988-1989 Transfer Binder] Fed. Sec. L. Rep. (CCH) I 94,181, at 91,644-45 (Del. Ch. Dec. 30, 1988); In re Fort Howard Corp. Shareholders Litig., No. 9991, slip op. at 35 (Del. Ch. Aug. 8, 1988), appeal denied, 547 A.2d 633 (Del. 1988).

48 See Revlon, 506 A.2d at 182; Paramount Communications, [Current] Fed. Sec. L. Rep. (CCH) at 93,277; see also In re Holly Farms Corp., [1988-1989 Transfer Binder] Fed. Sec. L. Rep. (CCH) at 91,644 (noting that once the target board "determined that it would sell the corporation ... [it] should have assumed the role of an 
Alternatively, the corporation may choose to wait for a market adjustment in its stock price, based on the belief that the market is currently undervaluing the target but will eventually increase its valuation to a price greater than the tender offer. ${ }^{49}$ Typically, the justification for such a belief rests upon either a discounted cash flow of the target's projected earnings, ${ }^{50}$ the break-up value of the target, ${ }^{51}$ or inside information regarding the target's business opportunities. ${ }^{52}$ The directors can simply wait for the expected market adjustment or use this projected market value as a lever in bargaining with the tender offeror.

Negotiating directly with the tender offeror for a higher price assumes that the target is worth more than the initial bid to the tender offeror. ${ }^{53}$ If this is so, the target board could conceivably negotiate a merger with the tender offeror for a price up to the tender offeror's subjective valuation of the target. ${ }^{54}$ Even if the target directors do not actively negotiate with the tender offeror,

auctioneer and it then became its duty to maximize the sales price . . . for the benefit of its shareholders"); Labaton, supra note 2, at D1, col. 3 ("[T]he Delaware justices said that once the sale of a company is inevitable, the directors must act as neutral auctioneers with the goal of obtaining the highest price.").

49 See Paramount Communications, [Current] Fed. Sec. L. Rep. (CCH) at 93,277; Gilson \& Kraakman, supra note 2 , at 262; supra note 36 (noting that the market does not efficiently price stock).

50 See Fabrikant, Warner Gets Good Price, Analysts Say, N.Y. Times, June 17, 1989, at A31, col. 6 (noting that Drexel Burnham valued Warner by "using a multiple of about nine time 1989 cash flow"); Fabrikant, supra note 37, at D6, col. 3 ("Wall Street analysts come up with their estimates using multiples of operating income from the [corporation's] various divisions.").

51 "The breakup value is the sum of a company's assets if sold separately." Fabrikant, supra note 50, at A31, col. 6; see also Fabrikant, supra note 39, at D21, col. 4 (noting that the break-up value of a corporation "is the yardstick by which Wall Street determines [its] value").

52 See Gilson \& Kraakman, supra note 2, at 262.

53 Some "subjectivist" economic theories suggest that the target may have a greater value to the tender offeror than to any other party. The Synergistic Gains Theory attributes the premium over the market price to anticipated synergistic effects from the combination of the target and tender offeror. See Andre, supra note 3, at 874 ("[T] he target [may have] a unique value to the bidder that exceeds its value to the market generally ... [due to] gains from synergy [as a] result of greater operating efficiencies or reduced financial risks."); Gilson \& Kraakman, supra note 2, at 261. The Inefficient Management Theory "suggests that a premium is paid in a tender offer because the target's assets will be worth more under the management of the bidder than they currently are as managed by the target." Andre, supra note 3, at 872 (citing Easterbrook \& Fischel, supra note 11, at 1173).

54 See W. Nicholson, Microeconomic Theory: Basic Principles and EXTENSIONS 427-28 (3d ed. 1985). 
obstructing the tender offer and asserting that the tender price is inadequate may cause the tender offeror to increase its bid. ${ }^{\mathbf{5 5}}$

If, after assessing the various options, the target's directors believe that a value greater than the tender price could be obtained for the shareholders, the board would reject the tender offer as inadequate and refuse to redeem the antitakeover device. ${ }^{56}$

At this point, the dispute reaches the courts. The tender offeror seeks an injunction to have the antitakeover device removed, asserting that its real purpose is to perpetuate the incumbent management. ${ }^{57}$ To support this contention, the tender offeror produces its own investment banker's evaluations of the target to demonstrate that the tender offer is the target shareholders' best possible option. ${ }^{58}$ In response, the target's directors claim that the antitakeover device is necessary to maximize shareholder wealth since the

55 See CRTF Corp. v. Federated Dep't Stores, 683 F. Supp. 422, 428 (S.D.N.Y. 1988) ("Typically, an initial tender offer is regarded as a tentative opening ploy, subject to revision with respect to its terms and upward price adjustment."); Bebchuk, supra note 9, at 930 ("[T] he shareholders might expect that rejection of the present bid would lead the present bidder to make a higher offer."); Tyson Raises Bid for Holly, N.Y. Times, June 21, 1989, at D4, col. 2 (noting that Tyson Foods raised its tender offer for Holly Farms from $\$ 63.50$ to $\$ 70$ per share eight months after its initial bid was thwarted by an antitakeover device).

56 See, e.g., Dynamics Corp. of Am. v. CTS Corp., 805 F.2d 705, 710 (7th Cir. 1986) ("[A]fter thoroughly and impartially considering a variety of alternative methods of maximizing the shareholders' wealth the [directors] . . . adopted the [antitakeover device] in order to maximize the price at which the company would be sold."); Andre, supra note 3, at 869 n.21 ("Target management's usual justification for opposing tender offers is that management has deemed the offer 'grossly inadequate.' Thus, management adopts defensive tactics to 'protect' its shareholders ...." (citing Moran v. Household Int'l, 500 A.2d 1346 (Del. 1985))); Matheson \& Norberg, supra note 9 , at 438 ("In essence, the board's decision to retain the corporation's independence, because it deems an offer 'inadequate', has been used by the courts to justify giving the board a free hand to effect this decision by whatever means the board believes necessary.").

57 See Andre, supra note 3, at 889 ("Once a tender offer has been rejected or successfully resisted by target management, it seems inevitable that lawsuits . . . will follow . . charg[ing] that management is more concerned with entrenching itself than with maximizing shareholder profits."); see also Paramount Seeks to Bar Time Directors, N.Y. Times, June 21, 1989, at D18, col. 4 ("Paramount attacked [the antitakeover device] as 'a deliberate, persistent pattern of entrenchment moves by management . .. ." "); In Media Giants' Takeover Battle, Power of Debt Is Starkly Revealed, N.Y. Times, June 18,1989, at A1, col. 1 (noting the view of some analysts that Time's management was trying to "preserve itself in the face of the perceived threat of being taken over").

58 See, e.g., Mills Acquisition Co. v. MacMillan, Inc., [1988-1989 Transfer Binder] Fed. Sec. L. Rep. (CCH) I 94,071, at 91,013 (Del. Ch. Oct. 18, 1988) (tender offeror claimed its takeover bid "represents the highest price available to [the target's] shareholders"), rev'd on other grounds, 559 A.2d 1261 (Del. 1989). 
tender price is less than the value that might be obtained if an alternative option is pursued. ${ }^{59}$ Thus, the question of whether the antitakeover device is actually promoting the interests of shareholders reduces to one of whose investment banker is more accurate in assessing the target's "full" value. ${ }^{60}$

\section{Director's Duties and Judicial Review}

\section{A. Directors' Fiduciary Duties}

Although the board of directors of a Delaware corporation is charged by the Delaware General Corporation Law ${ }^{61}$ with managing the business and affairs of the corporation, it also has a common law fiduciary duty to act in the shareholders' best interest. ${ }^{62}$ This fiduciary duty consists of two components: the duty of loyalty and the duty of due care. ${ }^{63}$ The fiduciary duty of loyalty requires the directors to

59 See Matheson \& Norberg, supra note 9, at 413. Target directors making these arguments face a Catch-22 dilemma. They are claiming that the tender offer is not equal to the "full" value of the company which they say may be realized through means other than accepting the tender offer. Yet, by doing so, the directors admit that the status quo ante-bellum (before the corporate control contest) was not a maximization of shareholder wealth. Therefore, the directors implicitly confess to the breach of their fiduciary duty to maximize shareholder wealth. See Oesterle, supra note 10 , at 145 .

60 See City Capital Assocs. v. Interco, Inc., 551 A.2d 787, 798-800 (Del. Ch.), appeal dismissed, 556 A.2d 1070 (Del. 1988); see also Grand Metro. PLC v. Pillsbury Co., 558 A.2d 1049, 1057 (Del. Ch. 1988) ("Investment bankers support and critique each side of the controversy over the more productive way to create shareholder value."); Bartlett, supra note 34, at D1, col. 1 ("[M]ore and more cases require judges to evaluate competing packages of arcane securities proffered by . . . various bidders, and that has elevated investment opinions to a position of primary importance.").

61 See Del. Code. AnN. tit. 8, § 141(a) (1983); see also Polk v. Good, 507 A.2d 531,536 (Del. 1986) ("Under Delaware law the business and affairs of a corporation are managed by and under the direction of its board of directors."); Revlon, Inc. v. MacAndrews \& Forbes Holdings, 506 A.2d 173, 179 (Del. 1986) ("The ultimate responsibility for managing the business and affairs of a corporation falls on its board of directors."); Unocal Corp. v. Mesa Petroleum Co., 493 A.2d 946, 953 n.6 (Del. 1985) ("The general grant of power to board of directors is conferred by . . . $\S 141$ (a), which provides: '(a) The business and affairs of every corporation organized under this chapter shall be managed by or under the direction of a board of directors ...." $)$.

62 See Grand Metro., 558 A.2d at 1055 (stating the basic principle that "corporate directors have a fiduciary duty to act in the best interests of the corporation's stockholders"); Revlon, 506 A.2d at 181 ("[T]he fiduciary standards outlined in Unocal ... require the directors to determine the best interests of the corporation and its stockholders . . . ."); Unocal, 493 A.2d at 955 ("[C]orporate directors have a fiduciary duty to act in the best interests of the corporations' stockholders.").

63 See Polk, 507 A.2d at 536 ("[T]he directors owe fundamental fiduciary duties 
act for corporate purposes rather than in their own self-interest. ${ }^{64}$ The fiduciary duty of due care requires the directors to have an informed basis for action. ${ }^{65}$ Where the directors are found to have breached either of these duties, a court may hold the directors liable for any resulting harm to the shareholders; where the directors are found to have breached the duty of loyalty, recision of the corporate transaction may result as well. ${ }^{66}$ Before the Unocal decision, the Delaware courts enforced the directors' fiduciary duties by employing two distinct standards for review of directors' actions: the business judgment rule and the intrinsic fairness test. ${ }^{67}$

\section{The Business Judgment Rule}

Under the business judgment rule, courts extend great deference to directors' actions. To satisfy this standard of judicial review, directors need only demonstrate that their decision can be "attributed to any rational business purpose." 68 Once directors have shown this, the business judgment rule affords a "presumption that in making a business decision the directors of a corporation acted on an informed basis, in good faith and in the honest belief that the action taken was in the best interests of the company."69 This presumption cannot be rebutted "unless it is shown by a preponderance of the evidence that the directors' decisions were primarily based on perpetuating themselves in office, or some other breach of fiduciary duty such as fraud, overreaching, lack of good faith, or being uninformed."70 Because each of these elements is difficult to prove,

of loyalty and care to the corporation and its shareholders."); Aronson v. Lewis, 473 A.2d 805, 811-12 (Del. 1984); Guth v. Loft, Inc., 5 A.2d 503, 510 (Del. 1939).

64 See Ivanhoe Partners v. Newmont Mining Corp., 535 A.2d 1334, 1345 (Del. 1987); Smith v. Van Gorkom, 488 A.2d 858, 872-73 (Del. 1985); Guth, 5 A.2d at 510; Note, supra note 9 , at 376.

65 See Ivanhoe Partners, 535 A.2d at 1345; Van Gorkom, 488 A.2d at 872-73; Anderson \& Bibi, supra note 33 , at 285-87.

66 See Gilson, A Structural Approach to Corporations: The Case Against Defensive Tactics in Tender Offers, 33 STAN. L. Rev. 819, 822-25 (1981); Note, supra note 9, at 376.

67 See Oesterle, supra note 10 , at 117,118 n.7.

68 Sinclair Oil Corp. v. Levien, 280 A.2d 717, 720 (Del. 1971); see also Robert M. Bass Group v. Evans, 552 A.2d 1227, 1239 (Del. Ch.) ("Under [the business judgment rule] standard, the transaction is presumed to be valid ... so long as it can be attributed to any rational business purpose."), appeal dismissed sub nom. MacMillan, Inc. v. Robert M. Bass Group, 548 A.2d 498 (Del. 1988); Unocal, 493 A.2d at 954 ("A hallmark of the business judgment rule is that a court will not substitute its judgment for that of the board if the latter's decision can be 'attributed to any rational business purpose." " (quoting Sinclair Oil, 280 A.2d at 720)).

(i) Aronson v. Lewis, 473 A.2d 805, 812 (Del. 1984).

7) Unocal, 493 A.2d at 958. 
courts rarely will find a breach of fiduciary duty when directorial decisions are subject to the business judgment rule. ${ }^{71}$

There are several justifications for the business judgment rule's mild review. First, courts lack expertise to make substantive evaluations of business decisions. ${ }^{72}$ Second, any evaluation made by the courts will have the benefit of hindsight, necessarily distorting judicial perception of the situation faced by the directors. ${ }^{73}$ Third, "the rule encourages informed risk taking by directors because it shields them from personal liability ...."74 And fourth, a stricter rule may deter qualified people from accepting directorships. ${ }^{75}$

These justifications for a deferential review of directors' actions, however, represent only part of the rationale for the business judgment rule. Of equal significance is the fact that the business judgment rule is applicable only to directorial decisions that occur in a particular context: ordinary business matters. ${ }^{76}$ While there is no

71 See In re Beatrice Cos. Shareholder Litig., No. 8248, slip op. at 13 (Del. Ch. Apr. 16, 1986), aff'd, 552 A.2d 865 (Del. 1987), cert. denied, 108 S. Ct. 233 (1987); Johnson \& Siegel, supra note 28, at 328; Matheson \& Norberg, supra note 9, at 415, 422; see also In re Fort Howard Corp. Shareholders Litig., No. 9991, slip op. at 30 (Del. Ch. Aug. 8, 1988) ("Rarely will direct evidence of bad faith . . be available."); Andre, supra note 3 , at $889-90$ (to overcome the presumptions afforded by the business judgment rule, "the plaintiff was required to show that the directors acted improperly or in bad faith. Such an evidentiary burden was not only difficult to sustain, but courts were loathe to bar application of the business judgment rule even upon a clear showing of blatant conflicts of interest" (footnote omitted)).

72 See Joy v. North, 692 F.2d 880, 886 (2d Cir. 1982), cert. denied, 460 U.S. 1051 (1983); West Point-Pepperell, Inc. v. J.P. Stevens \& Co., 542 A.2d 770, 780 (Del. Ch. 1988); Johnson \& Siegel, supra note 28, at 323 \& n.27; Veasey \& Mongan, supra note 28, at 460; Note, supra note 9, at 376; Note, False Halo: The Business Judgment Rule in Corporate Control Contests, 66 TEx. L. REv. 843, 846-47 (1988).

73 See Johnson \& Siegel, supra note 28, at 323 \& n.27; Note, supra note 72, at 846.

74 Note, supra note 72, at 846; see also Joy, 692 F.2d at 886; West Point-Pepperell, 542 A.2d at 780; Johnson \& Siegel, supra note 28, at 323 \& n.27; Veasey \& Mongan, supra note 28 , at 460 .

75 See Note, supra note 72 , at 846 . "This justification for the business judgment rule, however, is not as much a concern today... [since] several states [have] enacted statutes that permit corporations to limit the liability of their directors for breaches of fiduciary duties." Id. at 846 n.18; see, e.g., DeL. Code ANN. tit. 8, § 145(g) (1983) ("A corporation shall have power to purchase and maintain insurance on behalf of any person who is or was a director ... against any liability asserted against him and incurred by him in any such capacity ....").

76 See Polk v. Good, 507 A.2d 531, 536 (Del. 1986) ("Under Delaware law the business and affairs of a corporation are managed by and under the direction of its board of directors. ... Subject to certain well defined limitations, a board enjoys the protection of the business judgment rule in discharging its responsibilities." (citations omitted)); Pogostin v. Rice, 480 A.2d 619, 624 (Del. 1984) ("The bedrock of the General Corporation Law of the State of Delaware is the rule that the [ordinary] business and affairs of a corporation are managed by and under the 
precise definition of ordinary business matters, courts clearly distinguish between business decisions that concern day-to-day operations of the corporation and decisions which involve self-dealing transactions. ${ }^{77}$ The relative potential for directorial abuse is the basis for this distinction. Where the potential for directorial abuse is greater than that in ordinary business matters, the justifications for a deferential review are less compelling. ${ }^{78}$ Conversely, in the context of ordinary business matters, the potential for directorial abuse is minimal and does not outweigh the justifications for a deferential review of business decisions.

\section{The Intrinsic Fairness Test}

The greatest potential for directorial abuse occurs in corporate transactions that involve self-dealing, defined as transactions in

direction of its board."); In re RJR Nabisco, Inc. Shareholders Litig., [1988-1989 Transfer Binder] Fed. Sec. L. Rep. (CCH) I 94,194, at 91,709 (Del. Gh. Jan. 31, 1989) (" $[T]$ his action constitutes an attack upon a decision made by an apparently disinterested board in the exercise of its statutory power to manage the business and affairs of the corporation. That being apparently the case, the appropriate format or structure for judicial review of the action under attack would be provided by the business judgment rule ...." (citations omitted)); Matheson \& Norberg, supra note 9, at 449 n.154 ("The business judgment rule has its limits in all contexts."); Veasey, supra note 28, at 505 ("These decisions are often 'enterprise' or operational issues ('shall we buy a new truck?' or 'shall we give Mary a raise?')."); Note, Corporate Auctions and Directors' Fiduciary Duties: A Third Generation Business Judgment Rule, 87 Mich. L. REv. 276, 281 (1988) ("The traditional version of the business judgment rule covers operational decisions made by directors in the day-to-day conduct of the corporation's affairs .....").

77 See RJR Nabisco, [1988-1989 Transfer Binder] Fed. Sec. L. Rep. (CCH) at 91,710 ("The sort of 'interest' that qualifies to disarm a board at the outset of the benefits of a business judgment approach is a financial interest in the transaction adverse to that of the corporation or its shareholders."); Robert M. Bass Group v. Evans, 552 A.2d 1227, 1239 (Del. Ch.) ("[T]he [judicial] standard governing the propriety of [a corporate] transaction will depend upon the context or setting in which it arises."), appeal dismissed sub nom. MacMillan, Inc. v. Robert M. Bass Group, 548 A.2d 498 (Del. 1988); Ivanhoe Partners v. Newmont Mining Corp., 533 A.2d 585, 602 (Del. Ch.) (stating that the business judgment rule is applicable "where no self-dealing is shown"), aff'd, 535 A.2d 1334 (Del. 1987); Schreiber v. Pennzoil Co., 419 A.2d 952, 956 (Del. Ch. 1980) ("The business judgment rule is a presumption that a rational business decision of the ... directors of a corporation is proper unless there exists facts which remove the decision from the protection of the rule -such as self-dealing, conflict of interest, etc.").

78 See Lewis v. S.L. \& E., Inc., 629 F.2d 764, 769 (2d Cir. 1980) ("[T]he business judgment rule presupposes that the directors have no conflict of interest."), appeal dismissed, 746 F.2d 141 (2d Cir. 1984); Mills Acquisition Co. v. Macmillan, Inc., 559 A.2d 1261, 1279 (Del. 1989) ("[T]his judicial reluctance to assess the merits of a business decision ends in the face of illicit manipulation of a board's deliberative processes by self-interested corporate fiduciaries."). 
which "directors ... are on both sides."79 In this situation, the transaction lacks the objective indicia of an arm's-length exchange, enabling directors to enrich themselves at the shareholders' expense. $^{80}$ As a result, Delaware courts do not use the business judgment rule and instead apply a stricter form of judicial review known as the intrinsic fairness test. ${ }^{81}$ This test, codified in the Delaware General Corporation Law, ${ }^{82}$ requires that courts examine the substantive merits of the corporate transaction and uphold it only if the directors can demonstrate that the transaction was fair in its entirety to the corporation: ${ }^{83}$

The concept of fairness has two basic aspects: fair dealing and fair price. The former embraces questions of when the transaction was timed, how it was initiated, structured, negotiated, disclosed to the directors, and how the approval[] of the directors ... w[as] obtained. The latter aspect of fairness relates to the economic and financial considerations of the proposed [transaction], including all relevant factors ....84

Thus, the intrinsic fairness test essentially requires courts to make their own evaluation of the directors' action and to substitute their judgment for that of the directors.

\section{B. The Tender Offer Dilemma}

The tender offer context presents an anomalous situation for the courts' use of the business judgment rule and the intrinsic fairness test. An unsolicited tender offer enhances the potential for directorial abuse because the surrender of corporate control may be

79 Macmillan, 559 A.2d at 1279 (citing Weinberger v. UOP, Inc., 457 A.2d 701, 710 (Del. 1983)).

80 See Weinberger, 457 A.2d at 709 n.7, 710; see also RJR Nabisco, [1988-1989 Transfer Binder] Fed. Sec. L. Rep. $(\mathrm{CCH})$ at $91,710 \mathrm{n} .12$ (a self-dealing transaction occurs "when a financially interested party sets the terms of a transaction and compels its effectuation" (citations omitted)).

81 See Ivanhoe Partners, 535 A.2d at 1341; Weinberger, 457 A.2d at 710; Robert $M$. Bass Group, 552 A.2d. at 1239; Tate \& Lyle v. Staley Continental, [1987-1988 Transfer Binder] Fed. Sec. L. Rep. (CCH) \ 93,764, at 98,585 (Del. Ch. May 9, 1988).

82 "No contract or transaction between a corporation and 1 or more of its directors ... shall be void or voidable ... if ... [t] $]$ he contract or transaction is fair as to the corporation as of the time it is authorized ...." Del. CODE ANN. tit. 8, $\S 144(a)(3)$ (1983).

83 See Weinberger, 457 A.2d at 710; Robert M. Bass Group, 552 A.2d at 1239; Tate E Lyle, [1987-1988 Transfer Binder] Fed. Sec. L. Rep. (CCH) at 98,585; AC Acquisitions v. Anderson, Clayton \& Co., 519 A.2d 103, 111 (Del. Ch. 1986); Note, supra note 9 , at 376 .

84 Weinberger, 457 A.2d at 711 . 
detrimental to the directors' self-interest. ${ }^{85}$ In a transfer of corporate control, all directors face the prospect of losing their directorships. ${ }^{86}$ More importantly, inside directors may lose their lucrative management positions, ${ }^{87}$ and outside directors may lose benefits associated with their directorship duties and their relationship to the inside directors. ${ }^{88}$ Hence, the context of a corporate control contest presents a greater potential for directorial abuse than the ordinary business context of the business judgment rule. ${ }^{89}$ As a result, there is heightened concern over directorial abuse that vitiates the justifications for the business judgment rule's deferential review. ${ }^{90}$

At the same time, directors' self-interest in a corporate control transaction is not equivalent to that in a self-dealing transaction. While directors may benefit if a tender offer is prevented, they do not stand on both sides of the transaction, as they would in a selfdealing situation. ${ }^{91}$ Hence, there is little need for the intrinsic fair-

85 See Gilson \& Kraakman, supra note 2, at 263.

86 See Dynamics Corp. of Am. v. CTS Corp., 805 F.2d 705, 711 (7th Cir. 1986); Southdown, Inc. v. Moore McCormack Resources, 686 F. Supp. 595, 601 (S.D. Tex. 1988); Johnson \& Siegel, supra note 28, at 324; Prentice, Target Board Abuse of Defensive Tactics: Can Federal Law Be Mobilized to Overcome the Business Judgment Rule?, 8 J. CorP. L. 337, 343-44 (1983); Veasey, supra note 28, at 508; Note, supra note 9, at 377.

87 See Gilson \& Kraakman, supra note 2, at 247-48; Johnson \& Siegel, supra note 28, at 324-25; Kreider, supra note 4, at 135; Oesterle, supra note 10, at 130; see also Andre, supra note 3, at 877 n.75 ("A takeover is a traumatic event for target management. In its aftermath, dismissals are almost inevitable, and in some cases they decimate the executive staff of the target." (quoting Coffee, Regulating the Market for Corporate Control: A Critical Assessment of the Tender Offer's Role in Corporate Governance, 84 Colum. L. Rev. 1145, 1238 (1984))).

88 See Dynamics Corp. of Am. v. CTS Corp., 794 F.2d 250, 256 (7th Cir. 1986), rev'd on other grounds, 481 U.S. 69 (1987); Panter v. Marshall Field \& Co., 646 F.2d 271, 300-01 (7th Cir.), cert. denied, 454 U.S. 1092 (1981); Prentice, supra note 86, at 343; cf. supra note 33 (noting that outside directors may have the same interests as inside directors).

89 See Gilson \& Kraakman, supra note 2, at 247; cf. Kreider, supra note 4, at 123 ("[T] $]$ he conflict of interest that always exists in these circumstances by virtue of the very purpose of the tender offer, to wrest control of the corporation from its incumbent management, demands that courts not give unfettered discretion to management in opposing such offers."). Compare supra notes 76-78 and accompanying text (noting minimal potential for directorial abuse in ordinary business matters when the business judgment rule is applied) with supra notes 85-88 and accompanying text (noting directors' economic and non-economic interests involved in corporate control contests).

90 See Andre, supra note 3, at 890 ; Johnson \& Siegel, supra note 28 , at 324; Matheson \& Norberg, supra note 9, at 422; Note, supra note 9, at 374; Note, Tender Offer Defensive Tactics and the Business Judgment Rule, 58 N.Y.U. L. REv. 621, 623-24 (1983).

91 See BNS, Inc. v. Koppers Co., 683 F. Supp. 458, 475 (D. Del. 1988) ("The board's enactment of the [antitakeover device] . . . does not make the board 'interested[]'. . . ."). But see Gilson \& Kraakman, supra note 2, at 248 ("[R]esponding 
ness test's strict scrutiny of the substantive aspects of the directors' decision to combat a takeover attempt. ${ }^{92}$ Thus, neither the business judgment rule nor the intrinsic fairness test provides a suitable standard for judicial review of the use of antitakeover devices. ${ }^{93}$

In essence, the business judgment rule and the intrinsic fairness test simply balance two factors: the potential for directorial abuse and the desirability of judicial review of the substantive merits of directors' decisions. ${ }^{94}$ The justifications against judicial review of directors' decisions are equally applicable in all contexts. ${ }^{95}$ Where the potential for directorial abuse is minimal, as in ordinary business matters, these justifications outweigh concerns that the judicial review is needed to protect shareholders from their directors. ${ }^{96}$ Where the potential for directorial abuse is great, however, as in selfdealing transactions, concerns over shareholder interests outweigh the justifications against judicial review. ${ }^{97}$ Therefore, where the context of the directors' action falls between the paradigmatic extremes envisioned by each test, an intermediate level of judicial review is optimal. ${ }^{98}$

\section{Unocal's Intermediate Standard of Review}

In the landmark case Unocal Corp. v. Mesa Petroleum Co., ${ }^{99}$ the Delaware Supreme Court adopted an intermediate level of review for

to a hostile takeover is an interested transaction that calls for judicial review under the intrinsic fairness test. Yet, invoking this rigorous standard would simply condemn most defensive tactics without any justification beyond the standard itself.").

92 See Ivanhoe Partners v. Newmont Mining Corp., 535 A.2d 1334, 1341 (Del. 1987) (noting that the use of an antitakeover device does not require the application of the intrinsic fairness test).

93 See Easterbrook \& Fischel, supra note 11, at 1198; Gilson \& Kraakman, supra note 2, at 247; Kreider, supra note 4, at 135; Prentice, supra note 86, at 344-46.

94 See supra notes 72-84 and accompanying text.

95 See supra notes 72-75 and accompanying text (discussing justifications for the business judgment rule's deferential standard of review). It seems unlikely that the judiciary's expertise in evaluating corporate decisions will vary with the context of any particular decision.

96 See supra notes 76-78 and accompanying text (discussing the rationale for the business judgment rule's deferential review).

97 See supra notes 79-84 and accompanying text (discussing the rationale for the intrinsic fairness test's strict scrutiny of directors' decisions).

98 See BNS, Inc. v. Koppers Co., 683 F. Supp. 458, 473 (D. Del. 1988) ("The role of the Court in assessing the decisions made by directors in the hostile tender offer context is an intricate composite of deference to the business expertise of the directors and close scrutiny of incumbent management decisions.").

99493 A.2d 946 (Del. 1985). 
directorial actions designed to defeat takeover attempts. ${ }^{100}$ The court recognized that a target's directors are faced with an inherent conflict of interest in corporate control contests. ${ }^{101}$ Hence, any action that prevents the takeover bid raises "the omnipresent specter that a board may be acting primarily in its own interests, rather than [in] those of the corporation and its shareholders." 102 While noting that the business judgment rule still applied to directors' action in the tender offer context, the Unocal court imposed an "enhanced duty ... before the protections of the business judgment rule may be conferred." 103 Thus, the Court implicitly rejected the application of the intrinsic fairness test to this context. At the same time, however, the imposition of an "enhanced duty" on the board of directors created a standard of review more demanding than the business judgment rule.

This "enhanced duty," commonly known as the Unocal test, requires directors to demonstrate that their decision to use an antitakeover device to defeat the tender offer has satisfied two conditions. The first condition, hereinafter referred to as Unocal 1, demands that "directors ... show that they had reasonable grounds for believing that a danger to corporate policy and effectiveness existed." 104 The court stated that Unocal 1 is satisfied if the board shows " 'good faith and reasonable investigation'."105 Moreover, the court asserted that such proof would be "materially enhanced ...

100 The Unocal standard has been referred to as an intermediate review because it is not as demanding as the intrinsic fairness test, although it is stricter than the business judgment rule. See Gilson \& Kraakman, supra note 2, at 248; see also MAI Basic Four, Inc. v. v. Prime Computer, Inc., [1988-1989 Transfer Binder] Fed. Sec. L. Rep. (CCH) I 94,179, at 91,633-34 (Del. Ch. Dec. 20, 1988) ("A higher duty [than the business judgment rule] is imposed on a board, however, in connection with the adoption or implementation of anti-takeover measures."); City Capital Assocs. v. Interco, Inc., 551 A.2d 787, 796 (Del. Ch.) (noting that Unocal "created a new intermediate form of judicial review to be employed when a transaction is neither self-dealing nor wholly disinterested"), appeal dismissed, 556 A.2d 1070 (Del. 1988); Robert M. Bass Group v. Evans, 552 A.2d 1227, 1239 (Del. Ch.) ("A third, intermediate, standard [of review] applies to ... the context of [directorial action that obstructs] a pending takeover bid ...."), appeal dismissed sub nom. MacMillan, Inc. v. Robert M. Bass Group, 548 A.2d 498 (Del. 1988); AC Acquisitions v. Anderson, Clayton \& Co., 519 A.2d 103, 111 (Del. Ch. 1986) ("[T]he Delaware Supreme Court recognized in Unocal ... that where a board takes action designed to defeat a threatened change in control of the company, a more flexible, intermediate form of judicial review is appropriate.").

101 See Unocal, 493 A.2d at 954-55.

102 Id. at 954.

103 Id.

104 Id. at 955 (citing Cheff v. Mathes, 199 A.2d 548, 554-55 (Del. 1964)).

105 Id. (quoting Cheff, 199 A.2d at 555). 
by the approval of a board comprised of a majority of outside independent directors."106

The second condition, hereinafter referred to as Unocal 2, requires that the "defensive measure ... be reasonable in relation to the threat posed." 107 In a much quoted passage, the Unocal court stated that "[a] corporation does not have unbridled discretion to defeat any perceived threat by any Draconian means available."108 The court stated that the reasonableness test "entails an analysis ... of the nature of the takeover bid and its effect on the corporate enterprise."109 Moreover, the Court specified that appropriate concerns "may include: inadequacy of the price offered, nature and timing of the offer, questions of illegality, the impact on 'constituencies' other than shareholders . . ., the risk of nonconsummation, and the quality of securities being offered in the exchange."110

\section{Unocal As Applied to the Noncoercive Tender Offer}

\section{A. Unocal 1: Danger to Corporate Policy and Effectiveness}

In applying the Unocal test to a noncoercive tender offer, the first issue a court must address is whether the target's board has satisfied Unocal 1 in employing the antitakeover device. The Unocal court's articulation of this requirement, ${ }^{11}$ however, contains several ambiguities that have led to its inconsistent application by the lower courts.

\section{Good Faith and Reasonable Investigation}

In stating that Unocal $I$ is satisfied by a showing of "good faith and reasonable investigation," the Unocal opinion did not make clear

106 Id. A special committee composed of outside directors would meet the criterion of an independent board. See supra note 33 and accompanying text (stating that a special litigation committee of outside directors would have fewer conflicts of interest than a full board).

107 Unocal, 493 A.2d at 955. Unocal 2's reasonableness test has sometimes been referred to as the "proportionality" test. See Southdown, Inc. v. Moore McCormack Resources, 686 F. Supp. 595, 600-01 (S.D. Tex. 1988); Grand Metro. PLC v. Pillsbury Co., 558 A.2d 1049, 1056 (Del. Ch. 1988); City Capital Assocs. v. Interco, Inc., 551 A.2d 787, 796 (Del. Ch.), appeal dismissed, 556 A.2d 1070 (Del. 1988); Gilson \& Kraakman, supra note 2, at 248.

108 Unocal, 493 A.2d at 955.

109 Id.

110 Id. (citing Lipton \& Brownstein, Takeover Responses and Directors' Responsibilities: An Update, at 7 (Dec. 8, 1983) (presented at ABA National Institute on the Dynamics of Corporate Control)).

111 See supra notes 104-06 and accompanying text. 
whether this latter demonstration is intended to supersede the actual language of the Unocal 1 test, which requires "reasonable grounds for believing that a danger to corporate policy and effectiveness existed." 112 This distinction is significant because the two standards are not necessarily congruent. Since "reasonable grounds for believing" implies a reasonable investigation, the facial language of Unocal $I$ cannot be met without the use of good faith and reasonable investigation. ${ }^{113}$ The converse, however, is not necessarily true. It is possible for a board to act in good faith and employ a reasonable investigation and still not have "reasonable grounds for believing that a danger to corporate policy and effectiveness existed."114 The distinction lies in the object of the reasonable investigation; while the facial language of Unocal 1 demands the reasonable investigation of "a danger to corporate policy and effectiveness," the mere demonstration of "good faith and reasonable investigation" lacks a definitive object.

Because of this ambiguity, the lower courts have not agreed which standard satisfies Unocal 1. Most courts have taken the position that the facial language of Unocal 1 is the actual test and that the demonstration of "good faith and reasonable investigation" serves merely as a predicate to the type of investigation required. ${ }^{115}$ Some

112 Unocal, 493 A.2d at 955.

113 Directors are already obligated to exercise good faith and conduct a reasonable investigation by the business judgment rule. See supra text accompanying notes 68-69.

114 See, e.g., infra notes 205-06 and accompanying text (noting that the court in Panter v. Marshall Field \& Co., 646 F.2d 271 (7th Cir.), cert. denied, 454 U.S. 1092 (1981), upheld the use of an antitakeover device under the business judgment rule despite the lack of evidence concerning the threat the tender offer posed to the value of the target).

115 See, e.g., Ivanhoe Partners v. Newmont Mining Corp., 535 A.2d 1334, 1341 42 (Del. 1987) (discussing factors which led directors to reasonably believe that the tender offer posed a threat); Polk v. Good, 507 A.2d 531, 537 (Del. 1986) (requiring "reasonable grounds for a justifiable belief by the directors that there was a threat" despite a "prima facie showing of good faith and reasonable investigation"); Revlon, Inc. v. MacAndrews \& Forbes Holdings, 506 A.2d 173, 180-81 (Del. 1986) (discussing factors that led directors reasonably to believe that the tender offer posed a threat); Moran v. Household Int'l, 500 A.2d 1346, 1356 (Del. 1985) (noting reasonable grounds for board's perception of the threat to the target); Grand Metro. PLC v. Pillsbury Co., 558 A.2d 1049, 1059-60 (Del. Ch. 1988) (finding no threat to "corporate policy and effectiveness" despite demonstration of "good faith and reasonable investigation"); City Capital Assocs. v. Interco, Inc., 551 A.2d 787, 79899 (Del. Ch.) (noting board's reasonable investigation into inadequacy of tender price), appeal dismissed, 556 A.2d 1070 (Del. 1988); Nomad Acquisition Corp. v. Damon Corp., [1988-1989 Transfer Binder] Fed. Sec. L. Rep. (CCH) If 94,040, at 90,871 (Del: Ch. Sept. 16, 1988) (finding directors' "concern about general conditions in the merger and acquisition market" and the "specific threat from 
other courts have ruled that Unocal 1 may be satisfied simply by demonstrating good faith and reasonable investigation into a perceived threat; no showing of actual danger to corporate policy or effectiveness is necessary. ${ }^{116}$ In addition, these courts have held that the presence of an independent board majority shifts the burden of proof from the directors to the tender offeror. ${ }^{117}$

\section{Corporate Policy and Effectiveness and Shareholder Interests}

Even when a court does employ the facial language of Unocal 1, a serious ambiguity remains in that the Unocal opinion did not provide a definition of what constitutes a "danger to corporate policy and effectiveness."118 Consequently, the lower courts have been required to interpret this language themselves. Essentially, this task involves two related questions: 1) Does the tender offer affect "corporate policy and effectiveness"?; and 2) When will this effect be detrimental?

Whether a noncoercive tender offer affects "corporate policy and effectiveness" devolves into the question of whether "corporate policy and effectiveness" includes shareholder interests. It is generally accepted that a noncoercive tender offer only affects shareholder

Nomad's Schedule 13D filing" to constitute reasonable grounds to believe that there was a threat to corporate policy and effectiveness).

116 See BNS, Inc. v. Koppers Co., 683 F. Supp. 458, 474 (D. Del. 1988); CRTF Corp. v. Federated Dep't Stores, 683 F. Supp. 422, 437 (S.D.N.Y. 1988); Robert M. Bass Group v. Evans, 552 A.2d 1227, 1241 (Del. Ch.), appeal dismissed sub nom. MacMillan, Inc. v. Robert M. Bass Group, 548 A.2d 498 (Del. 1988); Tate \& Lyle v. Staley Continental, [1987-1988 Transfer Binder] Fed. Sec. L. Rep. (CCH) \ 93,764, at 98,585 (Del. Ch. May 9, 1988).

117 See, e.g., Polk, 507 A.2d at 537 ("[T] [out of 13] ... constitute[d] a prima facie showing of good faith and reasonable investigation. . . . [T]he plaintiffs thus bore a heavy burden of overcoming the presumptions thus attaching to the board's decisions."); MAI Basic Four, Inc. v. Prime Computer, Inc., [1988-1989 Transfer Binder] Fed. Sec. L. Rep. (CCH) I 94,179, at 91,634 (Del. Ch. Dec. 20, 1988) ("[W]here a majority of a board (6 out of 7) favoring the takeover defenses consisted of disinterested directors, the burden of persuasion falls upon the plaintiff to show a breach of the directors' fiduciary duties.").

118 See Gilson \& Kraakman, supra note 2, at 258-59. Unocal held that a coercive, two-tiered tender offer by a known greenmailer was a danger to corporate policy and effectiveness. See Unocal Corp. v. Mesa Petroleum Co., 493 A.2d 946, 956 (Del. 1985). This result follows from the fact that a successful greenmail attempt will deplete the corporation's assets, thereby affecting the corporation's ability to conduct its business operations. This example, however, sheds little light on what generally constitutes a danger to corporate policy and effectiveness, and, more specifically, whether an unsolicited tender offer constitutes such a danger. 
interests. ${ }^{119}$ This conclusion follows from the fact that a tender offer, in itself, will only change the actual ownership of the corporation; it does not in any way directly affect the corporation's ability to conduct its business activities. ${ }^{120}$ On the other hand, "corporate policy and effectiveness" literally seems to relate only to corporate operations; that is, the corporation's ability to conduct its current business activities. ${ }^{121}$ Hence, this category would not include shareholder interests. This literal definition, however, implies that the Unocal test does not permit directors to use antitakeover devices to act in the best interests of their shareholders, ${ }^{122}$ their primary fiduciary duty.

Faced with this apparent inconsistency between the literal wording of the Unocal test and its underlying policy considerations, ${ }^{123}$ courts have split as to whether shareholder interests affected by noncoercive tender offers fall within the scope of Unocal 1's "corporate policy and effectiveness" category. Most courts have held that "corporate policy and effectiveness" does encompass shareholder interests. ${ }^{124}$ This interpretation of "corporate policy and effectiveness"

119 See, e.g., Grand Metro., 558 A.2d at 1056 (stating that the noncoercive tender offer is not "a danger to policy or effectiveness of the Pillsbury corporation (that is, the company as company).... Whatever danger there is relates solely to shareholders and that concerns price only."); Interco, $551 \mathrm{~A} .2 \mathrm{~d}$ at 797 ("[I]n the special case of a tender offer for all shares, the threat posed, if any, is not importantly to corporate policies (as may well be the case in a stock buy-back case such as Cheff v. Mathes, 199 A.2d 548 (Del. 1964) or a partial tender offer case such as Unocal itself), but rather the threat, if any, is most directly to shareholder interests.").

120 While the change in ownership may eventually result in a change in the corporation's business operations (such as if the new owner liquidates or recapitalizes), concerns of this kind are not relevant to the considerations of directors as agents for current shareholders.

121 See Grand Metro., 558 A.2d at 1056. Although the distinction between the efficacy of the corporate enterprise and the shareholders' interest in stock prices appears to follow from a literal reading of "corporate policy and effectiveness," this result is somewhat illogical. The concern of directors should not vary between the shareholders' interest in actual corporate operations and the shareholders' interest in the exchange value of their stock.

122 See supra note 61 and accompanying text.

123 See AC Acquisitions v. Anderson, Clayton \& Co., 519 A.2d 103, 112 (Del. Ch. 1986) (recognizing inconsistency and replacing Unocal l's literal test with a test based upon policy considerations). But see Grand Metro., 558 A.2d at 1058-59 ("In the principal, if not in all, Delaware cases validating use of the [Poison] Pill, it is apparent that the purpose thereof was to create a 'defense' against hostile, coercive acquisition techniques. . . . It would be ironic, indeed, if those cases and the shareholderprotective principle which they created were now . . . applied against [a noncoercive tender offer which] ... pose[s] no threat of any kind to the corporate enterprise.").

124 See, e.g., Revlon, Inc. v. MacAndrews \& Forbes Holdings, 506 A.2d 173, 181 (Del. 1986) ("These standards [outlined in Unocal] require the directors to determine the best interests of the corporation and its stockholders . ..."); Nomad Acquisition 
provides that the directors' use of an antitakeover device will satisfy Unocal 1 if the tender offer presents a danger to shareholder interests.

Other courts have held that shareholder interests are not literally included within "corporate policy and effectiveness." 125 Under this reading, a noncoercive tender offer will not pose a danger to "corporate policy and effectiveness," and the directors' use of an antitakeover device can never satisfy the Unocal 1 test.

Still other courts have simply dispensed with analyzing a noncoercive tender offer's effect on shareholder interests in terms of Unocal l's "corporate policy and effectiveness." There appear to be two variations on this approach. In the first variation, the Delaware chancery court in AC Acquisitions v. Anderson, Clayton $\mathcal{E}^{2}$ Co. ${ }^{126}$ recognized that "[t]here is no evidence that the [noncoercive tender] offer . . . threatens injury to ... the [corporate] enterprise." 127 Nevertheless, the court held that Unocal 1 was satisfied despite that test's required showing of a "danger to corporate policy and effectiveness." Without actually questioning the Unocal test, the court "reinterpreted" Unocal 1 by stating that it is "simply a particularization of the more general requirement that a corporate purpose, not one personal to the directors, must be served by the [antitakeover device]."128 Thus, if the directors' justification for the antitakeover device was to promote shareholder interests, this corporate purpose would satisfy Unocal 1. The AC Acquisitions approach was subsequently followed in Samjens Partners I v. Burlington Industries ${ }^{129}$ In Samjens, a federal court applying Delaware law similarly "reinterpreted" Unocal 1 to require that "there . . . be a basis for the board to have concluded that the defensive measure served a proper corporate purpose."130 By substituting $A C$ Acquisitions' criterion of "valid corporate purpose" for

Corp. v. Damon Corp., [1988-1989 Transfer Binder] Fed. Sec. L. Rep. (CCH) I 94,040, at 90,872 (Del. Ch. Sept. 16, 1988) (approving directors' decision to adopt rights plan "as a means of protecting Damon's shareholders").

125 See, e.g., Grand Metro., 558 A.2d at 1056 ("The board must show that it had reasonable grounds for believing that a danger to corporate policy and effectiveness would exist if the [Poison] Pill were redeemed and shareholder choice permitted. ... I conclude that no showing has been made that there would be a danger to policy or effectiveness of the Pillsbury corporation ... if the Rights were redeemed and/or if Grand Met succeeds in its Tender Offer. Whatever danger there is relates solely to shareholders ....").

126519 A.2d 103 (Del. Ch. 1986).

127 Id. at 112.

128 Id.

129663 F. Supp. 614 (S.D.N.Y. 1987).

$130 I d$. at 626. 
Unocal 1's requirement of "a danger to corporate policy and effectiveness," the Samjens court found that the protection of shareholder interests was sufficient to satisfy Unocal $1 .^{131}$

The second variation more openly disregards the actual language of Unocal 1 and was recently enunciated in City Capital Associates $v$. Interco, Inc. ${ }^{132}$ The chancery court recognized that "in the special case of a [noncoercive tender offer], the threat posed, if any, is not importantly to corporate policies . . . but rather the threat, if any, is most directly to shareholder interests." ${ }^{133}$ Consequently, the court held that the directors' use of an antitakeover device can satisfy Unocal 1, even though a noncoercive tender offer does not affect corporate policy and effectiveness, so long as the board is protecting shareholder interests. ${ }^{134}$ The Interco approach differs from that of $A C$ Acquisitions and Samjens in that Interco requires that the antitakeover device protect shareholder interests whereas $A C$ Acquisitions and Samjens require that the antitakeover device serve a valid corporate purpose. ${ }^{135}$

\section{Danger from Noncoercive Tender Offers}

Courts which read Unocal 1's category of "corporate policy and effectiveness" to include shareholder interests receive no guidance from the Unocal opinion as to when a belief that a noncoercive tender offer presents a danger to such interests would be reasonable. ${ }^{136} \mathrm{~A}$ noncoercive tender offer threatens shareholder interests to the extent that the tender price is less than the target's "full" value in an alternative transaction. ${ }^{137}$ As noted above, there are four basic types

131 See id.

132551 A.2d 787 (Del. Ch.), appeal dismissed, 556 A.2d 1070 (Del. 1988).

133 Id. at 797.

134 See id. at 797-98 ("We have held that a board is not required simply by reason of the existence of a noncoercive offer to redeem outstanding poison pill rights.").

135 Compare id. at 796-99 (stating that the threat to shareholder interests posed by noncoercive tender offer can satisfy Unocal 1) with AC Acquisitions, $519 \mathrm{~A} .2 \mathrm{~d}$ at 112 (stating that a "valid corporate purpose" underlying the defensive maneuver can satisfy Unocal 1) and Samjens Partners I, 663 F. Supp. at 626 (stating that a defensive measure must serve a "proper corporate purpose").

136 Even though noncoercive tender offers affect shareholder interests, it does not necessarily follow that this effect is detrimental. See Gilson \& Kraakman, supra note 2, at 258-60.

137 See, e.g., BNS, Inc. v. Koppers Co., 683 F. Supp. 458, 475 (D. Del. 1988) ("[T]he inadequacy of the offering price does present a threat to the company and its stockholders."); Grand Metro. PLG v. Pillsbury Co., 558 A.2d 1049, 1056 (Del. Ch. 1988) ("Whatever danger there is relates solely to shareholders and that concerns price only."); Robert M. Bass Group v. Evans, 552 A.2d 1227, 1241 (Del. Ch.) ("The 
of alternative options that may yield this "full" value: undertaking an internal restructuring, engaging in a Revlon-style auction, simply waiting for a market adjustment, or negotiating directly with the tender offeror. ${ }^{138}$ Since each of these options involves an estimation of a potentiality, any measure of "full" value necessarily contains an element of uncertainty as to its realization. ${ }^{139}$ Thus, a court must determine whether the possibility of realizing a "full" value greater than the tender price could have led the directors to reasonably believe that the tender offer presented a danger to shareholder interests.

Despite the relevance of the probability of realizing "full" value to the reasonableness of the directors' belief, most courts have not directly addressed this issue in their Unocal 1 analysis. ${ }^{140}$ However, some courts have dismissed valuations where the investment banker was not impartial or where the estimates were based upon pie-in-the-

Court thus concludes that if the [noncoercive] offers posed a cognizable, reasonably perceived threat, it was only in the minimal sense that the [tender price], although fair, is less than the highest price that the defendants' financial advisors believed might be obtained [through alternative means]."), appeal dismissed sub nom. MacMillan, Inc. v. Robert M. Bass Group, 548 A.2d 498 (Del. 1988); supra note 36 and accompanying text (noting that a noncoercive tender offer will be in the shareholders' best interest only where it represents the target's "full" value).

A tender offer at a price lower than the target's "full" value, however, is not a threat unless there is a probability that the target's shareholders will tender their shares. In other words, the tender offer is a threat if the directors are correct in their valuation of the target and the shareholders do not believe the directors. See Interco, 551 A.2d at 798; Gilson \& Kraakman, supra note 2, at 259-60.

138 See supra notes 38-42 and accompanying text.

139 See supra note 37 and accompanying text; infra text accompanying notes 152 53.

140 See BNS, Inc., 683 F. Supp. at 473-75; Revlon, Inc. v. MacAndrews \& Forbes Holdings, 506 A.2d 173, 181 (Del. 1986); MAI Basic Four, Inc. v. Prime Computer, Inc., [1988-1989 Transfer Binder] Fed. Sec. L. Rep. (CCH) \ 94, 179, at 91,634 (Del. Ch. Dec. 20, 1988); Nomad Acquisition Corp. v. Damon Corp., [1988-1989 Transfer Binder] Fed. Sec. L. Rep. (CCH) I 94,040, at 90,871-72 (Del. Ch. Sept. 16, 1988); Doskocil Co. v. Griggy, No. 10,095, slip op. at 7 (Del. Ch. Aug. 4, 1988); Tate \& Lyle v. Staley Continental, [1987-1988 Transfer Binder] Fed. Sec. L. Rep. (CCH) I 93,764, at 98,585 (Del. Ch. May 9, 1988).

One suspects that the courts' aversion to assessing the reasonableness of the directors' belief that the tender offer poses a danger to shareholder interests is due to the similarity of this analysis to the reasonableness test in Unocal 2. While these two evaluations are alike in some respects, they are not identical. In Unocal 1, the reasonableness of the directors' belief only focuses upon the probability that the target's "full" value may be greater than the tender offer price. The Unocal 2 reasonableness test, on the other hand, examines whether the antitakeover device is in the shareholders' best interests. As such, Unocal 2 requires an analysis not only of the probability of a "full" value greater than the tender price but also the probability that the tender offer may be withdrawn or reduced in value. Cf. infra notes 143-50 and accompanying text (discussing elements of Unocal 2's reasonableness test). 
sky projections. ${ }^{141}$ Other courts have found valuations suspect where a "reasonable" period of time had elapsed since the tender offer and the directors had not yet realized the "full" value. ${ }^{142}$

\section{B. Unocal 2: Reasonable in Relation to Threat Posed}

Once a court has found that the directors have satisfied the requirements of Unocal 1 , it will then proceed to the second element of the Unocal test. This element requires the court to decide whether the enactment or maintenance of an antitakeover device is "reasonable in relation to the threat posed."143 As noted above, the Unocal court stated that "[a] corporation does not have unbridled discretion to defeat any perceived threat by any Draconian means available."144 Since all antitakeover devices can effectively thwart tender offers, ${ }^{145}$ the nature of the perceived threat alone determines whether the device is Draconian. ${ }^{146}$

The perceived threat from a tender offer may be defined in terms of the relationship between the tender price, the probability of realizing the "full" value of the target, and the probability that the target will be worth less than the tender price if the tender offer is defeated. ${ }^{147}$ If the tender offer is given the opportunity to succeed, shareholders may not obtain the "full" value for their stock. As a result, the shareholders will lose the difference between the "full" value and the tender price. ${ }^{148}$ However, if the antitakeover device

141 See supra note 34.

142 See, e.g., Southdown, Inc. v. Moore McCormack Resources, 686 F. Supp. 595, 602-03 (S.D. Tex. 1988) (noting that since the company had beyond a reasonable time to consider and respond to a tender offer, "the company appears to be for sale only on terms that are acceptable to management but that will not necessarily benefit the stockholders").

143 Unocal Corp. v. Mesa Petroleum Co., 493 A.2d 946, 955 (Del. 1985).

144 Id.

145 See supra note 9 and accompanying text; see also Paramount Communications v. Time, Inc., [Current] Fed. Sec. L. Rep. (CCH) I 94,514, at 93,284 (Del. Ch. July $14,1989)$ ("[E]ffectuation of the Warner merger may practically [negatively] impact the likelihood of a successful takeover of the . . company . . . ."), aff'd sub nom. Literary Partners v. Time, Inc. (Del. July 24, 1989) (available on LEXIS and WESTLAW).

146 See Matheson \& Norberg, supra note 9, at 461 (" [A] takeover defense may not be voided merely because of its effectiveness . ..."). 139.

147 See supra note 137 and accompanying text; supra text accompanying note

148 See supra note 36 and accompanying text (noting that a tender offer at a premium above the market price may not be in the shareholders' best interest); supra note 137 and accompanying text (noting that a tender offer threatens shareholder interests to the extent that the tender price is less than the target's full value). 
prevents the tender offer, the shareholders are denied the opportunity to tender their shares at a premium above the market price. If the directors are unable to realize the "full" value and the tender offer is subsequently withdrawn or reduced in value, the shareholders will lose the difference between the original tender price and the subsequent value of the target's stock. ${ }^{49}$

Thus, the reasonableness test requires a court to engage in a "calculus" of harms: a factual determination of what course of action is in the shareholders' best interests. ${ }^{150}$ Set forth in terms of an equation, an antitakeover device is in the shareholders' best interests if

$$
(\mathrm{FV}-\mathrm{TP})(\mathrm{pFV})-(\mathrm{TP}-\mathrm{SV})(\mathrm{pSV})>0
$$

where "FV" is a "full" value greater than the tender price, "TP" is the tender price, "pFV" is the probability of realizing this "full" value if the antitakeover device is maintained, "SV" is the subsequent value of the target's stock if the directors have not realized the "full" value and the tender offer is withdrawn or revised downwards, and "pSV" is the probability that SV shall occur. The only factor in

149 See, e.g., Paramount Communications, [Current] Fed. Sec. L. Rep. (CCH) at 93,265 (" $[\mathrm{I}] \mathrm{t}$ is very unlikely that the market price of Time stock immediately following consummation of the now planned two-stage Warner transaction will equal the initial $\$ 175$ price offered by Paramount."); Grand Metro. PLC v. Pillsbury Co., 558 A.2d 1049, 1058 (Del. Ch. 1988) (noting potential loss to shareholders "if the Pill remains in place and Grand Met's offer is withdrawn"); Fabrikant, supra note 39, at D21, col. 4 ("[A]nalysts have said that if Time succeeds in fighting off [the Paramount] bid ... Time's stock could fall initially to about $\$ 140$ a share [from the $\$ 175$ a share offered by Paramount]."); MAI Basic Lowers Bid for Prime Computer, N.Y. Times, June 2, 1989, at D4, col. 1 (noting that MAI Basic Four lowered its bid from $\$ 20$ per share to $\$ 18$ per share six months after its initial tender offer was obstructed by an antitakeover device); see also Gilson \& Kraakman, supra note 2, at 264 ("[W]hen first offers are defeated and no second offer follows, share prices for target firms eventually sink back to their pre-offer levels and thus inflict heavy opportunity costs on target shareholders."); Jensen \& Ruback, The Market for Corporate Control: The Scientific Evidence, 11 J. FIN. Econ. 5, 38 (1983) ("Currently available evidence suggests that managerial opposition to a takeover does not reduce shareholder wealth unless the resistance eliminates potential takeover bids.").

150 See, e.g., Robert M. Bass Group v. Evans, 552 A.2d 1227, 1241-42 (Del. Ch. 1988) ("A reasonable response, then, would be to develop a more valuable economic alternative [to the tender offer]."), appeal dismissed sub nom. MacMillan, Inc., v. Robert M. Bass Group, 548 A.2d 498 (Del. 1988); Veasey, supra note 28, at 512 ("'D]ecisions will be examined for 'reasonableness' - a concept which implies an objective determination by the court."); Note, supra note 76, at 287 ("The reasonableness prong allows a court to strike down defensive tactics where the potential harmful effects of the tactics outweigh the threat identified by the board."(footnote omitted)). 
the reasonableness equation which is precisely known is TP; the value of the other quantities may only be approximated. ${ }^{151}$

Unocal 2's reasonableness test suffers from a significant interpretational dilemma. The Unocal court did not indicate the degree of scrutiny a court should use in analyzing the reasonableness of an antitakeover device. ${ }^{152}$ In particular, courts have been given no guidance on how to estimate the reasonableness equation's unknown quantities. A court's dilemma is particularly acute in the noncoercive tender offer model because the target's and the tender offeror's investment bankers typically produce conflicting estimates of the unknown factors. ${ }^{153}$

151 See supra note 37.

152 See, e.g., Gilson \& Kraakman, supra note 2, at 253 (noting that Unocal contemplates a form of substantive review by a court, but leaves unanswered the rigor with which the standard is to be applied).

153 See supra notes 58-60 and accompanying text. A second ambiguity in Unocal 2 is whether the noncoercive tender offer's effect on shareholder interests constitutes a "threat posed." The Unocal opinion created considerable confusion by failing to describe this term in the language of "danger to corporate policy and effectiveness" used in Unocal 1. Compare supra text accompanying note 104 (Unocal 1 uses "danger to corporate policy and effectiveness") with supra text accompanying note 107 (Unocal 2 uses "threat posed"). As a result, one could infer that the two are not equivalent.

An examination of the Unocal court's description of the Unocal 2 test does not resolve this ambiguity. Unocal 2 requires an "analysis by the directors of the nature of the takeover bid and its effect on the corporate enterprise." Unocal Corp. v. Mesa Petroleum Co., 493 A.2d 946, 955 (Del. 1985). This modifies "threat" in two respects: 1) the threat relates to the nature of the takeover bid, and 2) the object of the threat is the "corporate enterprise." Id. The nature of the takeover bid appears to refer to the tender offer's structure and the consideration proposed. This reading finds clear support in three of the court's stated examples of directorial concern: the inadequacy of price, the nature and timing of the tender offer, and the quality of the securities offered. See id. Since these considerations relate primarily to shareholder interests, one could argue that Unocal 2's "threat posed" may be broader than Unocal l's "corporate policy and effectiveness" depending upon how this latter term had been defined by the court. On the other hand, the reference to the "corporate enterprise" as the object of the "threat posed" appears sufficiently similar to Unocal I's category of "corporate policy and effectiveness" that one may equate the two. As a consequence, the lower courts have not unanimously defined "threat posed" to include the noncoercive tender offer's effect on shareholder interests.

Some courts have defined "threat posed" as encompassing any threat to any corporate interest that includes shareholder interests. See, e.g., BNS, Inc. v. Koppers Co., 683 F. Supp. 458, 473, 475 (D. Del. 1988) (stating that "inadequacy of the offering price does present a threat to the company and its stockholders[,]" thus implying that the definition of "threat" includes more than mere threats to the corporate enterprise, and creating suspicion that a threat of any kind will satisfy Unocal 2); Polk v. Good, 507 A.2d 531, 537 (Del. 1986) (interpreting "threat" to include danger to the interests of "the corporation and its stockholders"); AC Acquisitions v. Anderson, Clayton \& Co., 519 A.2d 103, 112 (Del. Ch. 1986) (interpreting "threat" to include "injury to shareholders or to the enterprise").

Other courts have defined "threat posed" in terms of Unocal l's "danger to 
The ambiguity in assessing an antitakeover device's reasonableness has resulted in lower courts applying different degrees of substantive analysis. Some courts, in assessing the reasonableness of an antitakeover device, have engaged in a significant substantive review of whether the antitakeover device is in the shareholders' best interests. For instance, in Dynamics Corp. of America v. CTS Corp., ${ }^{154}$ Judge Posner remanded the district court's order approving an antitakeover device on the ground that the record did not sufficiently demonstrate the device's reasonableness. ${ }^{155}$ Devoting nine pages to an examination of the evidence on record, Judge Posner questioned why the antitakeover device contained its particular triggering percentage and triggering price. ${ }^{156}$ Notwithstanding the testimony of a "qualified financial expert" and an investment banker, Judge Posner held that the record created a serious doubt as to whether CTS had satisfied the requirement that "the reservation price . . . be reasonably related to the value of the corporation."157 Because Judge Posner was purporting to apply the "clearly erroneous" standard of appellate review, ${ }^{158}$ his opinion appears to indicate that an antitakeover device cannot be reasonable unless the directors can demonstrate with certainty that it will maximize shareholder wealth.

corporate policy and effectiveness." Those cases that have defined Unocal 2's "threat" in terms of the Unocal 1 analysis do not share a common definition of threat because of the different interpretation used in Unocal 1. Therefore, some courts have held that Unocal 2's concept of threat includes threats to shareholder interests. See, e.g., CRTF Corp. v. Federated Dep't Stores, 683 F. Supp. 422, 440 (S.D.N.Y. 1988) (stating that the Unocal 2 "threat" includes any threat to shareholder interests). Other courts, however, have held that "threat posed" does not include shareholder interests. See, e.g., Grand Metro. PLC v. Pillsbury Co., 558 A.2d 1049, 1058 (Del. Ch. 1988) ("Is the Board's defensive measure . . . 'reasonable in relation to the threat posed?'. . . [T]he only 'threat posed' here is to shareholder value-nothing whatsoever affects the corporate entity or any other constituency." (quoting Unocal, 493 A.2d at 955)).

This difference in interpretation, however, will not affect the analysis under the noncoercive tender offer model. As stated above, a noncoercive tender offer poses a threat only to shareholder interests. As such, the interpretation of "threat" under Unocal 2, which encompasses any threat to any corporate interest, will include threats to shareholder interests. Similarly, the interpretation of Unocal 2's threat, which is equated with Unocal 1's category of "corporate policy and effectiveness," will also include threats to shareholder interests if the court has already defined this category to encompass such interests. In the event the court has not done so, the use of the antitakeover device will not have satisfied Unocal 1, so this interpretation of Unocal 2 will not be relevant.

154805 F.2d 705 (7th Cir. 1986).

155 See id. at $709,717$.

156 See id. at 709-17.

157 Id. at $709,712,717$.

158 See id. at 708-09. 
Most courts, however, apply the reasonableness test by making superficial assessments of the "full" value and the tender price. ${ }^{159}$ Though this "minimalist" form of review will generally lead a court to rubber-stamp the directors' action and uphold the use of the antitakeover device, ${ }^{160}$ the court will not always find that the antitakeover device is reasonable. For instance, a court engaging in "minimalist" review will find an antitakeover device unreasonable when it believes the device will obstruct tender offers representing the "full" value of the target; that is, when the antitakeover device's trigger price is greater than reasonable expectations of the target's "full" value. ${ }^{161}$ In addition, some courts have found antitakeover devices not able to prevent harm to the shareholders to be unreasonable. Such a situation exists when the antitakeover device is used to

159 See Gilson \& Kraakman, supra note 2, at 252-53 (noting that the Delaware Supreme Court in Unocal, Revlon, and Moran appeared to use a "minimalist" review in applying the reasonableness test); Matheson \& Norberg, supra note 9, at 441 ("As evidenced by Unocal and Moran, court review of antitakeover measures has resulted in minimal scrutiny of these actions ....").

160 See, e.g., BNS, Inc. v. Koppers Co., 683 F. Supp. 458, 461, 475 (D. Del. 1988) (finding antitakeover device reasonable even though the tender offer was at a premium over the market price and the directors had not developed a more valuable alternative); CRTF Corp. v. Federated Dep't Stores, 683 F. Supp. 422, 439 (S.D.N.Y. 1988) (finding antitakeover device reasonable based on hindsight, without any consideration of the "full" value of the target); Ivanhoe Partners v. Newmont Mining Corp., 535 A.2d 1334, 1342, 1345 (Del. 1987) (finding antitakeover device reasonable because tender price was less than estimates of "full" value); Polk v. Good, 507 A.2d 531, 537 (Del. 1986) (finding greenmail payment reasonable after superficial review); Moran v. Household Int'l, 500 A.2d 1346, 1356-57 (Del. 1985) (finding antitakeover device reasonable because there existed a possibility of a prospective coercive tender offer); Unocal Corp. v. Mesa Petroleum Co., 493 A.2d 946, 956-57 (Del. 1985) (finding antitakeover device reasonable because tender price was less than directors' valuation of target); Nomad Acquisition Corp. v. Damon Corp., [1988-1989 Transfer Binder] Fed. Sec. L. Rep. (CCH) II 94,040, at 90,872 (Del. Ch. Sept. 16, 1988) (finding antitakeover device reasonable because directors received expert advice that the tender price was less than the target's "full" value); Tate \& Lyle v. Staley Continental, [1987-1988 Transfer Binder] Fed. Sec. L. Rep. (CCH) If 93,764, at 98,587 (Del. Ch. May 9, 1988) (upholding antitakeover device because target expressed desire to seek out either a white knight or financing for a restructuring); Facet Enters. v. Prospect Group, No. 9746, slip op. at 17-19 (Del. Ch. April 15, 1988) (upholding antitakeover device because the directors believed that an auction would maximize shareholder wealth); Johnson \& Siegel, supra note 28, at 333 ("[C]ourts have given directors tremendous latitude in assessing the reasonableness of the directors' response and have invalidated only those responses that are blatantly unreasonable."); Note, supra note 76, at 288 ("Delaware courts, in practice, show great deference toward a target board's reasonable determination that an offer poses a threat to the corporate enterprise."); supra note 159.

161 See, e.g., CRTF Corp., 683 F. Supp. at 439 (noting that an antitakeover device which is a "show stopper"- - one that contains a "price barrier to discourage offers below a perhaps artificially high trigger price"-will be "in and of itself, invalid"). 
protect a proposed alternative to the tender offer that is not more valuable than the tender price or the prevailing market price. ${ }^{162}$ These holdings, however, are inapplicable to the noncoercive tender offer model since the alternative to the tender offer in these cases was a known value that was less than the tender price, rather than an uncertain "full" value greater than the tender price. ${ }^{163}$

Other courts have applied the Unocal 2 reasonableness test without using the reasonableness equation. For instance, in MAI Basic Four, Inc. v. Prime Computer, ${ }^{164}$ the court's reasonableness test involved a "careful[] review [of] all the factors having a bearing on the course pursued by the directors."165 The MAI Basic Four court essentially adopted an ad hoc balancing test, describing various factors to be considered and then mysteriously arriving at a result. The factors considered by the court included: the relationship between the market price and tender price; the probability of realizing the target's "full" value (a function of the investment banker's projected value of the target, the possibility of a recapitalization, and the directors' ability to extract a better tender price from the tender offeror through hard bargaining); the good faith of the board (the presence of independent board majority and absence of evidence of any entrenchment motive); the directors' diligence in reaching their decision; the percentage of shares tendered by the shareholders; the coerciveness of the tender offer's structure; and the desirability of shareholder franchise. ${ }^{166}$

Other courts have defined the reasonableness of an antitakeover device in terms of time, by examining the directors' opportunity to realize the target's "full" value. ${ }^{167}$ This formulation recognizes that

162 See BNS, Inc., 683 F. Supp. at 475; Grand Metro. PLC v. Pillsbury Co., 558 A.2d 1049, 1057-59 (Del. Ch. Dec. 20, 1988); City Capital Assocs. v. Interco, Inc., 551 A.2d 787, 798-99 (Del. Ch.), appeal dismissed, 556 A.2d 1070 (Del. 1988); Mills Acquisition Co. v. MacMillan, [1988-1989 Transfer Binder] Fed. Sec. L. Rep. (CCH) If 94,071, at 91,021 (Del. Ch. Oct. 18, 1988), rev'd on other grounds, 559 A.2d 1261 (Del. 1988); Doskocil Co. v. Griggy, No. 10,095, slip op. at 7 (Del. Ch. Aug 4, 1988); Robert M. Bass Group v. Evans, 552 A.2d 1227, 1241-44 (Del. Ch.), appeal dismissed sub nom. Macmillan, Inc. v. Robert M. Bass Group, 548 A.2d 498 (Del. 1988); AC Acquisitions v. Anderson, Clayton \& Co., 519 A.2d 103, 113-14 (Del. Ch. 1986).

163 See, e.g., Robert M. Bass Group, 552 A.2d at 1241-44 (holding that an antitakeover device that is used to protect a restructuring with a value less than the tender offer is an unreasonable response).

164 [1988-1989 Transfer Binder] Fed. Sec. L. Rep. (CCH) I 94,179 (Del. Ch.

Dec. 20, 1988).

165 Id. at 91,634 .

166 See id. at 91,634-35.

167 See Southdown, Inc. v. Moore McCormack Resources, 686 F. Supp. 595, 604 (S.D. Tex. 1988) (noting that the target's board was unsuccessful in soliciting 
the realization of "full" value depends on the directors' ability to pursue alternative options. This ability to develop alternatives, in most cases, is primarily a function of time. For instance, a restructuring requires several weeks for the target's investment banker to develop a plan and arrange the necessary financing. ${ }^{168}$ Likewise, in order to conduct a Revlon-style auction, the target must provide potential white knights with enough time to assess the target's value and raise sufficient capital for the transaction. ${ }^{169}$ If the target has been unsuccessful in its attempt to develop a restructuring plan or to find a white knight once the necessary time for these alternative options has passed, it is unlikely to succeed even if given further time. ${ }^{170}$ Therefore, under this approach, a court will recognize the probability that the directors can realize the "full" value for only a limited period of time. Once that period has expired, however, the court will no longer recognize this potentiality.

competitive bids, and that in the five weeks that the tender offer was outstanding, the market indicated a fair price for the target similar to the tender offer price); Samjens Partners I v. Burlington Indus., 663 F. Supp. 614, 626 (S.D.N.Y. 1987) (stating that target corporation's self-tender was a reasonable response to an inadequate hostile tender offer since designed to allow the target board to consider alternatives to maximize shareholder wealth); see also In re Holly Farms Corp. Shareholders Litig., [1988-1989 Transfer Binder] Fed. Sec. L. Rep. (CCH) I 94,181, at 91,645 (Del. Ch. Dec. 30,1988 ) (" $[T]$ he poison pill ... may still have a role in maximizing values. At some future time, the poison pill may no longer serve a valid purpose but that time has not yet arrived."); City Capital Assocs. v. Interco, Inc., 551 A.2d 787, 798 (Del. Ch.) ("[T] here may come a time when a board's fiduciary duty will require it to redeem the [antitakeover device] . ..."), appeal dismissed, 556 A.2d 1070 (Del. 1988).

168 A restructuring, depending on the type of plan, can be completed within two to three months. See Anderson \& Bibi, supra note 33, at 298. Most restructuring plans, however, can be completed in a much shorter period of time. See id. at 296-97, 299; see also Matheson \& Norberg, supra note 9, at 409 (noting that "[i]nnovative forms of financing and changes in the banking climate make it now possible ... to raise billions of dollars in a matter of weeks"). The two to three month time period refers only to those recapitalizations and spin-offs which require either shareholder approval or an SEC registration requirement. See Anderson \& Bibi, supra note 33, at 295, 298-99. Hence, the time period necessary to develop the restructuring plan is significantly less than that required to comply with the formal aspects of implementing the plan.

169 See Andre, supra note 3, at 908 (noting that twenty business days is "too short a time to conduct an auction"); infra notes 230-32 and accompanying text (noting that two months is sufficient time to locate a white knight).

170 See Southdown, 686 F. Supp. at 602 (noting that the target should have been able to find a white knight within forty days); Grand Metro. PLC v. Pillsbury Co., 558 A.2d 1049, 1057 (Del. Ch. 1988) (noting that if a competitive bid was a possible alternative to the tender offer, it would have occurred within two months); supra notes 168 \& 169 and accompanying text; infra notes $230-32$. 


\section{A Skeleton's Key for the $U_{\text {NOCAL }}$ Test's Ambiguities}

This Comment's examination of the Unocal test's application to the noncoercive tender offer model has revealed that the test's present formulation is inadequate. The Unocal test contains several ambiguous elements which are susceptible to contradictory interpretations, thereby impeding the realization of consistent and uniform outcomes. ${ }^{171}$

This Comment recommends that courts adopt the two following proposals to rectify these dilemmas. First, the Unocal test's ambiguous elements ought to be interpreted by reference to two fundamental principles inherent in the Unocal analysis: 1) The duty of directors to act in the shareholders' best interest ${ }^{172}$ (hereinafter referred to as the Shareholder Interest Principle); and 2) The appropriateness of an intermediate standard of review ${ }^{173}$ (hereinafter referred to as the Intermediate Review Principle). These principles should provide sufficient guidance to the courts, giving Unocal's ambiguous terms a standard meaning and thereby promoting the uniform application of the test.

When the Unocal test has been applied to the noncoercive tender offer model, the following elements have been subject to contradictory interpretations by the lower courts:

1. Is the requirement that the directors demonstrate "reasonable grounds for believing that a danger to corporate policy and effectiveness existed" satisfied by a showing of "good faith and reasonable investigation"? ${ }^{174}$

171 See supra notes 111-70 and accompanying text.

172 See Unocal Corp. v. Mesa Petroleum Co., 493 A.2d 946, 955 (Del. 1985); supra note 62; see also Revlon, Inc. v. MacAndrews \& Forbes Holdings, 506 A.2d 173, 181 (Del. 1986) ("[T]he fiduciary standards outlined in Unocal . . . require the directors to determine the best interests of the corporation and its stockholders ....").

This principle seems to have been adopted by Judge Posner in Dynamics Corp. of America v. CTS Corp., 805 F.2d 705 (7th Cir. 1986). While purporting to enunciate the standard of the Unocal test, Judge Posner stated a variant of the Unocal test emphasizing directors' fiduciary duty to maximize shareholder wealth:

[T] ] particular [antitakeover device the board] adopts must be reasonably related to the goal of shareholder wealth maximization. . . . [C]ourts are not simply to rubber stamp the board's judgment but must review it carefully to make sure that in adopting the poison pill the board really was acting in the best interests of the corporation. See, e.g., Unocal Corp. v. Mesa Petroleum Co., 493 A.2d 946, 954-55 (Del. 1985).

Id. at 708 .

173 See supra notes $99-110$ and accompanying text.

174 See supra notes $112-17$ and accompanying text. 
2. Does the category of "corporate policy and effectiveness" include the shareholder interests affected by noncoercive tender offers? ${ }^{175}$

3. Under what circumstances will a noncoercive tender offer constitute a danger to shareholder interests, and what probability of realizing a "full" value greater than the tender price is sufficient for the tender offer to constitute such a danger? ${ }^{176}$

4. How is a court to assess whether the antitakeover device is a reasonable response "in relation to the threat posed"? 177

The contradictory responses to each of these questions could be eliminated, and the ambiguities in the Unocal test resolved, if courts were to refer to the two proposed Principles.

\section{A. Good Faith and Reasonable Investigation Alone Do Not Satisfy Unocal 1}

Most courts have held that a showing of good faith and reasonable investigation, without more, is insufficient to satisfy Unocal 1's requirement of "reasonable grounds for believing that a danger to corporate policy and effectiveness existed" because of the tender offer. ${ }^{178}$ Other courts, relying on Unocal 1's equivocal language, have ruled otherwise. ${ }^{179}$ As noted above, the majority position constrains the scope of the directors' investigation to dangers affecting "corporate policy and effectiveness"; the minority position imposes no such limitation. ${ }^{180}$ This conflict of interpretation may be resolved by reference to the Intermediate Review Principle.

The minority position's standard of review, like that of the business judgment rule, will uphold the actions of directors upon a showing of good faith and reasonable investigation. ${ }^{181}$ As a result, the Unocal 1 test becomes "a toothless standard for testing whether directors have fulfilled their duty of loyalty." 182 The majority position, though, imposes a stricter scrutiny since the narrow judicial focus on the object of investigation necessarily limits the board's discretion. Instead of a simple showing of good faith and reasonable investigation, the board must demonstrate the existence of reason-

175 See supra notes $118-35$ and accompanying text.

176 See supra notes $136-42$ and accompanying text.

177 See supra notes $143-70$ and accompanying text.

178 See supra note 115 and accompanying text.

179 See supra notes 116 \& 117 and accompanying text.

180 See supra notes $112-15$ and accompanying text.

181 See supra notes $68-69$ \& 116 and accompanying text.

182 Johnson \& Siegel, supra note 28 , at 330 . 
able grounds for believing the presence of "a danger to corporate policy and effectiveness." 183 The majority position represents the better interpretation since it is more compatible with the Intermediate Review Principle. ${ }^{184}$

\section{B. Unocal I's Category of Corporate Policy and Effectiveness Should Include Shareholder Interests}

As noted above, the courts are divided on whether a noncoercive tender offer's effect on shareholder interests falls within Unocal I's category of "corporate policy and effectiveness." Some courts have ruled that this term includes shareholder interests, others have held that it does not, and some courts have even rejected the use of this term in the Unocal 1 analysis. ${ }^{185}$ This dispute among the courts may be resolved by reference to the two proposed guidelines for interpreting Unocal.

Though the view that "corporate policy and effectiveness" does not include shareholder interests may conform with a strict reading of the language of the Unocal 1 test, it has the consequence of preventing directors from using antitakeover devices to obstruct any noncoercive tender offer. ${ }^{186}$ Since a takeover bid in fact may harm shareholder interests, ${ }^{187}$ this interpretation conflicts with the Shareholder Interest Principle and should be rejected. ${ }^{188}$

183 See supra notes 112-14 and accompanying text.

184 The minority position is inferior because it cannot be reconciled with a natural reading of the Unocal opinion. Indeed, the minority position completely dismisses the articulated language of the Unocal 1 test. The Delaware Supreme Court's statement that a demonstration of good faith and reasonable investigation satisfies Unocal 1 presumably was not made in a vacuum apart from the other language of the test. A natural reading of the Unocal opinion appears to indicate that the court intended the criteria of good faith and reasonable investigation to refer to the board's belief that there was a danger to corporate policy and effectiveness. Likewise, the court's reference to the independent board majority reflects the empirical presumption that outside directors face a less significant conflict of interest than inside directors. See Southdown, Inc. v. Moore McCormack Resources, 686 F. Supp. 595, 601 (S.D. Tex. 1988); supra notes 33-35 and accompanying text. But see M. EISENBERG, supra note 33, at 145; Johnson \& Siegel, supra note 28, at 382; supra notes $33 \& 88$ and accompanying text. Therefore, these qualifiers to the Unocal 1 test ought not alter the substantive requirement that the directors present evidence to demonstrate that they had reasonable grounds to believe that the tender offer presented a "danger to corporate policy and effectiveness."

185 See supra notes $123-35$ and accompanying text.

186 See supra note 125 and accompanying text.

187 See supra notes 36 \& 121 ; supra note 137 and accompanying text.

188 This interpretation of Unocal $l$ is also fallacious because it contradicts subsequent statements by the Delaware Supreme Court and Chancellor Allen that the Unocal test may permit the use of antitakeover devices to prevent tender offers. 
The rejection of the "corporate policy and effectiveness" category in favor of a valid corporate purpose test is also an inappropriate interpretation of Unocal 1. The dismissal of the language of Unocal 1 is grounded on a literal interpretation of "corporate policy and effectiveness" and departs from the valued policy of permitting directors to act in the shareholders' interest. ${ }^{189}$ This rationale, however, is satisfactory only to the extent that the resulting interpretation is consistent with the Intermediate Review Principle. If Unocal 1 is satisfied where the antitakeover device merely serves a valid corporate purpose, the level of judicial scrutiny is effectively reduced to that of the business judgment rule. ${ }^{190}$ As such, this interpretation should be rejected.

The view that "corporate policy and effectiveness" includes shareholder interests appears to be the best reading of Unocal 1. This interpretation is consistent with the Shareholder Interest Principle because it permits directors to use antitakeover devices to protect shareholders from the possible harm caused by noncoercive tender offers. In addition, this view does not cause the Unocal test to deviate from an intermediate level of review; directors still must show reasonable grounds for believing the tender offer a danger to shareholder interests. ${ }^{191}$

\section{A Noncoercive Tender Offer is a Danger to Shareholder Interests Where the Tender Price is Less Than a "Full" Value Projection}

The courts have also disagreed about what constitutes a reasonable belief that a noncoercive tender offer threatens shareholder interests. As noted above, this question addresses the reasonableness of the directors' belief that "full" value may be greater than the tender price. ${ }^{192}$ Some courts have found the directors' belief unreasonable when based upon biased or improbable projections of the target's value or when the directors had not realized a "full" value

See Moran v. Household Int'l, 500 A.2d 1346, 1352 (Del. 1985); City Capital Assocs. v. Interco, Inc., 551 A.2d 787, 798 (Del. Ch.), appeal dismissed, 556 A.2d 1070 (Del. 1988).

189 See supra notes 121-22 and accompanying text.

190 See supra note 69 and accompanying text.

191 This requirement imposes a greater burden than the business judgment rule. See supra notes $183-84$ and accompanying text.

192 See supra text accompanying notes 137-39. 
despite ample time to do so. ${ }^{193}$ Most courts, however, have not addressed this issue. ${ }^{194}$

The most appropriate method by which to evaluate the reasonableness of a belief in the potentiality of a "full" value may be determined by reference to both the Intermediate Review Principle and the Shareholder Interest Principle. Those courts that do not address the reasonableness of the directors' belief will find the Unocal 1 test of the antitakeover device congruent with the business judgment rule. By not examining the reasonableness of the directors' belief, this position interprets Unocal 1 to require only that the noncoercive tender offer affect "corporate policy and effectiveness." Since all noncoercive tender offers affect "corporate policy and effectiveness" as defined above by the Shareholder Interest Principle, ${ }^{195}$ this formulation of Unocal 1 would not impose an "enhanced duty" upon the directors and should be rejected.

Some courts have held that a belief is unreasonable where the board has not realized a "full" value after a considerable period of time. This position, however, is inconsistent with the Shareholder Interest Principle. While some of the alternatives intended to realize a "full" value may have standard time-frames, ${ }^{196}$ other options, such as negotiating with the tender offeror for a higher price or waiting for a market adjustment, do not. ${ }^{197}$ Any judicial analysis in which a fixed period of time is dispositive impedes the directors' ability to realize a "full" value. Therefore, an interpretation of Unocal 2 which produces such an analysis is undesirable. ${ }^{198}$

In contrast, other courts have held that the directors' belief is reasonable provided it is not based upon biased or unrealistic projections. This position is concordant with both the Shareholder Interest Principle and the Intermediate Review Principle. Further, it imposes no constraints on the directors' ability to promote shareholder interests since it does not enjoin the antitakeover device where "full" value may probably be realized. ${ }^{199}$ At the same time, this position provides for an intermediate review of the directors' action. By requiring directors to demonstrate the potentiality of realizing a "full" value, this formulation imposes a greater duty than

193 See supra notes 141-42 and accompanying text.

194 See supra note 140.

195 See supra text accompanying note 191.

196 See supra notes $168-70$ and accompanying text.

197 See infra notes 218-20 and accompanying text.

198 See infra notes $218-20$ and accompanying text.

199 See infra notes 218-20 and accompanying text. 
does the business judgment rule, which does not demand such a particular presentation of evidence. ${ }^{200}$ In addition, this reading of Unocal 1 avoids the pitfalls of the intrinsic fairness test because the courts do not independently assess the target's "full" value to verify the legitimacy of the directors' belief. ${ }^{201}$ In light of the Intermediate Review Principle and the Shareholder Interest Principle, this Comment advocates an interpretation of Unocal 1 that requires the directors to present evidence of the probability of realizing "full" value if the tender offer is obstructed by the antitakeover device.

A somewhat similar position has been put forward in an article by Gilson and Kraakman. ${ }^{202}$ The authors suggest that Unocal should "require[] a showing of how-and when-management expects a target's shareholders to do better. ... [M]anagement must set forth its plan in sufficient detail to permit the court independently to evaluate the plausibility of management's claim."203 Gilson and Kraakman's proposal, however, differs from that of this Comment. The authors imply that courts should make an independent evaluation of the directors' projection of "full" value. ${ }^{204}$ Since such a substantive analysis demands a judicial review similar to that of the intrinsic fairness test, it conflicts with the Intermediate Review Principle and is therefore undesirable.

Critics of this Comment's proposed interpretation of Unocal 1 might contend that it imposes no greater duty than does the business judgment rule, which upholds antitakeover devices promoting a valid corporate purpose. In the context of a noncoercive tender offer, the only such purpose is to increase shareholder wealth by enabling management to pursue an alternative option. As such, critics might conclude that under the business judgment rule, directors must present the same evidence as that required by the proposed Unocal 1 interpretation. This criticism, however, is flawed because the business judgment rule's due diligence component does not require presentation of evidence that the target's "full" value is greater than

200 See supra notes $183-84$ and accompanying text.

201 See supra note 83 and accompanying text; supra text following note 84; see also supra note 92 and accompanying text.

202 See Gilson \& Kraakman, supra note 2.

203 Id. at 268.

204 Compare supra text following note 84 (stating that the intrinsic fairness test requires courts to make an independent evaluation of the directors' decision) with Gilson \& Kraakman, supra note 2, at 270-71 ("[T] he court must be free to exercise its independent judgment in weighing whether management's plans present a plausible story: a goal that improves on the value of the hostile offer and a means that is reasonably likely to achieve the goal."). 
the tender price. This point is dramatically illustrated in Panter $v$. Marshall Field $\mathcal{F}^{\circ}$ Co., ${ }^{205}$ where the Seventh Circuit found that the directors had satisfied the business judgment rule despite the "striking paucity of evidence on how [the target's] value might have been 'diminished by a [hostile tender] offer.',206

Other critics might contend that a court's blind acceptance of valuations done by the target's investment banker will invite inaccurate projections. While this concern has merit given the diminished credibility of investment bankers, ${ }^{207}$ this argument has two main weaknesses. First, courts could reduce the potential for self-serving valuations by requiring the investment banker to demonstrate some degree of independence from the tender offeror, perhaps by foregoing compensation on a contingency fee basis. ${ }^{208}$ Second, an institutional barrier discourages inaccurate projections since such projections may damage the investment banker's reputation in the financial community. ${ }^{209}$

\section{Reasonableness of the Antitakeover Device: In Search of Intermediate Judicial Review}

As demonstrated above, courts have diverged widely in applying Unocal 2's reasonableness test to the use of an antitakeover device. Some courts have utilized the reasonableness equation with varying degrees of scrutiny, others have assessed reasonableness in terms of time, and still another has adopted an ad hoc balancing test. ${ }^{210}$ These analyses are inadequate since each violates the Shareholder Interest Principle, the Intermediate Review Principle, or both.

The use of the reasonableness equation, either in its minimalist or strict scrutiny form, is incompatible with the Intermediate Review Principle. As noted above, the reasonableness equation will uphold an antitakeover device where $(\mathrm{FV}-\mathrm{TP})(\mathrm{pFV})-(\mathrm{TP}-\mathrm{SV})(\mathrm{pSV})>$ $0 .^{211}$ Any application of the reasonableness equation requires a court to make findings regarding the equation's unknown elements:

205646 F.2d 271 (7th Cir.), cert. denied, 454 U.S. 1092 (1981).

206 Id. at 306 n.14 (Cudahy, C.J., concurring in part and dissenting in part) (quoting majority opinion, id. at 296).

207 See supra note 34.

208 Cf. Dynamics Corp. of Am. v. CTS Corp., 805 F.2d 705, 710-11 (7th Cir. 1986) (holding that investment banker's valuation lacked credibility because investment banker's compensation was contingent upon the target defeating the tender offer).

209 See Gilson \& Kraakman, supra note 2, at 272.

210 See supra notes 150-70 and accompanying text.

211 See supra text preceding note 151 . 
"FV," "pFV," "SV," and "pSV.",212 Depending upon the court's degree of analysis in determining these quantities, the standard of review will resemble either the intrinsic fairness test or the business judgment rule.

Where a court employs the strict scrutiny version of the reasonableness equation and endeavors to estimate precisely these variables, it is effectively making an independent evaluation of the situation facing the directors. ${ }^{213}$ Such a substantive review of the merits of the directors' decision resembles the intrinsic fairness test's strict scrutiny, and is therefore undesirable. ${ }^{214}$

Conversely, where a court employs the minimalist version of the reasonableness equation and is satisfied with less precise estimates of the equation's unknown variables, the court is effectively deferring to the directors' decision in a manner akin to the business judgment rule.

Both the minimalist interpretation and the business judgment rule will enjoin an antitakeover device under the same circumstances. For instance, courts using the minimalist version of the reasonableness equation have found an antitakeover device unreasonable where it protects a restructuring valued at less than the tender price, ${ }^{215}$ or where the trigger price of the antitakeover device is not based on reasonable expectations of the target's "full" value. ${ }^{216}$ The business

212 See supra note 153 and accompanying text.

213 See supra notes $155-59$ and accompanying text.

214 See, e.g., Paramount Communications v. Time, Inc., [Current] Fed. Sec. L. Rep. (CCH) I 94,514, at 93,283-84 (Del. Ch. July 14, 1989) ("[T]he innovative and constructive rule of Unocal must be cautiously applied lest the important benefits of the business judgment rule (including designation of authority to make business and financial decisions to agencies: i.e., boards of directors, with substantive expertise) be eroded or lost by slow degrees."), aff'd, Literary Partners v. Time, Inc. (Del. July 24, 1989) (available on LEXIS and WESTLAW); City Capital Assocs. v. Interco, Inc., 551 A.2d 787, 796 (Del. Ch.) ("The danger that [Unocal's reasonableness test] poses is, of course, that courts - in exercising some element of substantive judgment - will too readily seek to assert the primacy of their own view on a question upon which reasonable, completely disinterested minds might differ."), appeal dismissed, 556 A.2d 1070 (Del. 1988); Johnson \& Siegel, supra note 28, at 333 ("Analyzing the seriousness of the threat and the appropriateness of the directors' response to that threat, however, requires the courts to substitute their business judgment for that of the directors."); Kreider, supra note 4, at 128 (in deciding "whether a reasonable belief exists that the actions taken are in the best interests of the corporation ... courts are second guessing to some degree the 'business judgment' of the directors by imposing their own judgments in the interest of fairness to shareholders"); Oesterle, supra note 10, at $118 \mathrm{n.7}$ (questioning whether the reasonableness test differs from the intrinsic fairness test).

215 See supra note 162 and accompanying text.

216 See supra note 161 and accompanying text. 
judgment rule would also enjoin the antitakeover device in both of these cases. In the former case, the measure would be enjoined because the antitakeover device does not serve a valid business purpose; in the latter case, because the unreasonable projections do not satisfy the due diligence component of the business judgment rule. ${ }^{217}$

Thus, the use of the equation to assess the reasonableness of the antitakeover device converts the Unocal test into a standard of review resembling either the business judgment rule or the intrinsic fairness test. As a result, the Intermediate Review Principle rejects the use of the reasonableness equation as Unocal 2's reasonableness test.

Other methods used by the courts to evaluate the reasonableness of antitakeover devices are also undesirable. Although assessing the reasonableness of an antitakeover device in terms of time $\mathrm{e}^{218}$ avoids the inherent dilemma of the reasonableness equation, it conflicts with the Shareholder Interest Principle, and is consequently unacceptable. Time constraints on the use of an antitakeover device severely handicap a target board's ability to negotiate with the tender offeror for a better price. When the target's value would be maximized under the tender offeror's ownership, and this value is greater than the tender price, the target board could reasonably expect that negotiations with the tender offeror would result in a better offer. ${ }^{219}$ If a court enjoined the use of an antitakeover device after a specified period of time, the tender offeror would refuse to negotiate with the target board and simply wait out the time period. Likewise, if the target's "full" value can be realized only by waiting for a market adjustment, a time limit on the use of an antitakeover device would preclude this option as well. As a consequence, the target's shareholders would lose the difference between the "full" value and the tender price. Therefore, evaluating the reasonableness of an antitakeover device in terms of time is undesirable. ${ }^{220}$

In contrast to the time-oriented approach, the MAI Basic Four ad hoc balancing test is not necessarily in conflict with either the Shareholder Interest Principle or the Intermediate Review Principle. A court conceivably could employ such a balancing test in a manner compatible with both of these principles. An ad hoc balancing test,

217 See supra notes 68-69 and accompanying text.

218 See supra notes $167-70$ and accompanying text.

219 See supra notes 53-55 and accompanying text.

220 Cf. MacAndrews \& Forbes Holdings v. Revlon, Inc., 501 A.2d 1239, 1251 (Del. Ch. 1985) ("The function of the Court is not to define the terms of negotiations in advance ....'), aff'd, 506 A.2d 173 (Del. 1986). 
however, is seriously flawed because it impinges upon society's need for predictable and uniform judicial decisions. ${ }^{221}$ Although the $M A I$ Basic Four court concluded that the directors' use of the antitakeover device in that case was reasonable, it did not apply a specific test in making its decision. ${ }^{222}$ Since it has no underlying rationale, the opinion has minimal precedential value; subsequent courts cannot employ usefully MAI Basic Four's holding when a different set of facts is encountered. ${ }^{223}$ In addition, the adoption of an ad hoc balancing test to determine the reasonableness of an antitakeover device would increase the likelihood of inconsistent outcomes. Therefore, this form of analysis should also be rejected.

Since these versions of the reasonableness test are inadequate, a new formulation of the review consistent with Unocal's underlying principles is needed. The Shareholder Interest Principle indicates that an antitakeover device ought to provide the directors with an opportunity to realize the target's "full" value. As noted above, the ability to realize a "full" value is a function of time for two of the four alternative options that the board may pursue. ${ }^{224}$ Consequently, this Comment proposes that courts assess the reasonableness of an antitakeover device by reference to the following set of presumptions which relate to the time directors need to develop alternatives to a tender offer. The proposed presumptions are as follows:

1. For the first two months after the commencement of the tender offer, ${ }^{225}$ the antitakeover device will be presumed unreasonable unless the directors present evidence that there is a probability of realizing a "full" value greater than the tender price. Such evidence consists of an investment banker's projection that the target

221 See J. White \& R. Summers, Uniform Commercial Code $§ 7$, at 20 (3d ed. 1988); see also Oesterle, supra note 10, at 118 (noting concern "over the prospect of unpredictable, ad hoc decisions in tender offer cases"); Veasey, supra note 28, at 512 (warning against "random ad hoc decisions" in the review of antitakeover devices).

222 See MAI Basic Four, Inc. v. Prime Computer, [1988-1989 Transfer Binder] Fed. Sec. L. Rep. (CCH) I 94,179, at 91,635 (Del. Ch. Dec. 20, 1988).

223 In addition, the MAI Basic Four analysis is inappropriate because it departed from the type of review required by Unocal. The MAI Basic Four court did not use the reasonableness equation and included other elements in its determination of reasonableness, thereby misconstruing the Unocal test. Compare supra text preceding note 166 (listing factors the MAI Basic Four court considered) with supra text preceding note 151 (describing the elements in the reasonableness equation).

224 See supra notes 167-70 and accompanying text.

225 Frequently, the tender offeror will seek to enjoin the antitakeover device upon announcing her intention to make a tender offer. For the purposes of the proposed presumptions, the announcement of such an intention will be treated as equivalent to the commencement of the tender offer. 
may have a "full" value greater than the tender price if an alternative option is pursued. ${ }^{226}$

2. After the two-month period, the antitakeover device will be presumed unreasonable unless the directors demonstrate that there is a substantial probability of maximizing shareholder wealth through negotiations with the tender offeror. This evidence consists of an investment banker's projection that the target's subjective value to the tender offeror is substantially greater than the tender price. ${ }^{227}$

If the target's directors satisfy this burden, they will then have a duty to engage in good faith negotiations with the tender offeror to realize this value. ${ }^{228}$ While this duty to negotiate does not compel the target's directors to agree to a merger with the tender offeror for a price less than the projected "full" value, it does require that the directors actively attempt to realize this "full" value. This duty is consistent with the directors' fiduciary duty of loyalty and creates a constraint on the directors' inherent conflict of interest in corporate control contests. ${ }^{229}$

These presumptions are compatible with the Shareholder Interest Principle because they enable the directors to realize the target's "full" value. The initial presumption will uphold an antitakeover device if the directors demonstrate that there is a probability of realizing a "full" value. The presumption will not prevent the directors from pursuing any alternative option that may enhance shareholder wealth. While the second presumption does limit the directors' options to negotiating only with the tender offeror, this constraint is

226 This is essentially a restatement of this Comment's proposed interpretation of Unocal 1. See supra text following note 201.

227 "Substantially greater" shall mean any projection where the "full" value exceeds the tender price by at least twenty percent of the tender price's premium over the pre-tender market price. In terms of an equation, a "full" value will be substantially greater than the tender price where $.2(\mathrm{FV}-\mathrm{TP})-(\mathrm{TP}-\mathrm{MP})=0$. This requirement recognizes that the shareholders' interests may not be served when a tender offer significantly above the market price is prevented, and perhaps eventually reduced or withdrawn, in an attempt to ensure one more dollar for each shareholder. While the proposed percentage is necessarily arbitrary, this requirement is necessary to protect shareholders.

228 The definition of "good faith negotiations" will be the same as that of the "obligation to bargain collectively" in the National Labor Relations Act, namely, "to meet at reasonable times and confer in good faith with respect to ... the negotiation of an agreement, . . . but such obligation does not compel either party to agree to a proposal or require the making of a concession." 29 U.S.C. $§ 158(d)$ (1982).

229 See supra notes $62 \& 64$ and accompanying text; infra notes 242-44 and accompanying text. 
justified in light of the practical aspects of the other alternatives. ${ }^{230}$ If the target cannot develop an adequately financed restructuring plan within two months after announcement of the tender offer, it is unlikely to succeed in doing so at all. ${ }^{231}$ Similarly, two months of unsuccessful solicitation of a white knight indicates the improbability that a suitor will suddenly change its mind and proffer a competing bid. ${ }^{232}$ The one option the second presumption precludes is waiting for the market to recognize the "full" value of the target.

As noted above, the market is not necessarily an accurate measure of a corporation's true value. ${ }^{233}$ Consequently, the preclusion of potential market appreciation is detrimental to shareholder interests if the target directors are correct in their valuation. ${ }^{234}$ Conversely, the shareholders are not denied the opportunity to realize the premium paid by the tender offeror when the directors are incorrect. A comparison of the potential harm in each scenario indicates that the shareholders will suffer more where the tender offer is obstructed indefinitely. Empirical evidence suggests that there is little likelihood of market appreciation after a tender offer is withdrawn. ${ }^{235}$ Moreover, if the target is substantially undervalued by the market, the directors could engage in either a restructuring or a Revlon-style auction since the investment banker's evaluation of these options draws from data similar to that used to project potential market appreciation. ${ }^{236}$

230 While the establishment of a two-month limit for the target may appear arbitrary, other commentators have proposed similar time periods for which the use of defensive tactics is justified. Lipton suggests that the target board should be given 120 calendar days "to evaluate a bid and to consider alternatives. . . . Such an extension would give the board a realistic opportunity to determine whether the target is best served by remaining independent or, if a sale is desired, whether the first offeror has made the most advantageous bid . . . " Lipton, supra note 36, at 62 . Similarly, Andre proposes that tender offers should remain open for sixty calendar days as opposed to the twenty business days required by current securities law. See Andre, supra note 3 , at 908 . He reasons that this period would "provide ample time for prospective bidders to research the target and make offers. . . " Id. at 908-09.

231 See supra notes 169-70 and accompanying text.

232 See supra notes 169-70 and accompanying text.

233 See supra notes 3 \& 49 and accompanying text.

234 See supra notes $49-52$ and accompanying text.

235 See supra note 149 and accompanying text.

236 Compare supra notes $43-45$ (noting that the valuation of a restructuring is dependent upon the value of the company's assets) and supra note 46 (noting that a bidder's valuation of the target reflects the value of the target's assets) with supra notes 50-52 and accompanying text (noting that the belief that market appreciation will occur is based on the underlying value of the target's assets). Gilson and Kraakman state that if managers are correct in their expectation of market appreciation, they "have a fiduciary responsibility to attempt to correct [the] 
The proposed presumptions concerning an antitakeover device's reasonableness are consistent with the Intermediate Review Principle. Both presumptions place a greater burden on the target directors than does the business judgment rule. ${ }^{237}$ These presumptions, however, are not as strict as the intrinsic fairness test since they do not require the courts independently to evaluate the probability that a "full" value may be realized. ${ }^{238}$.

Critics might contend that this Comment's imposition of a duty on the target directors to negotiate a merger with the tender offeror is contrary to the Delaware General Corporation Law. That statute provides in its relevant parts that the directors have the authority to decide whether to engage in a merger or not. ${ }^{239}$ Given this mandate, this Comment's proposal conflicts with the directors' legislatively granted authority to govern a corporation.

Whether the directors' duty of loyalty requires the maximization of current share value in the context of a noncoercive tender offer is an issue that has not been directly addressed by the Delaware courts. ${ }^{240}$ In essence, this question relates to issues of corporate governance that are beyond the scope of this Comment. ${ }^{241}$ It is sufficient to note that Chancellor Allen has indicated that this duty may exist where a tender offer is not conditioned upon financing arrangements or the directors' agreement to negotiate a merger with the

underpricing." Gilson \& Kraakman, supra note 2, at 269 n.72. If management is able to increase the market price above the tender price, the antitakeover device would no longer be necessary since shareholders would probably not tender their shares.

237 The business judgment rule's duty of due care does not demand that the directors present the type of evidence required by the proposed presumptions. See supra notes 183, 200, 205-06 and accompanying text.

238 See supra notes 82-84 and accompanying text; supra text preceding note 85 . 239 See Del. Code AnN. tit. 8, § 251(b) (1983 \& Supp. 1988) ("The board of directors of each corporation which desires to merge or consolidate . . ." (emphasis added)).

240 See BNS, Inc. v. Koppers Co., 683 F. Supp. 458, 475-76 (D. Del. 1988); TW Servs., Inc. v. SWT Acquisition Corp., [Current] Fed. Sec. L. Rep. (CCH) I 94,334, at 92,181 (Del. Ch. Mar. 2, 1989); see also Paramount Communications v. Time, Inc., [Current] Fed. Sec. L. Rep. (CCH) I 94,514, at 93,278-81 (Del. Ch. July 14, 1989) (stating that although under the particular facts Time's directors were not required to maximize current share value, "a decision not to redeem a poison pill . . . may present distinctive considerations than those presented in this case"), aff'd sub nom. Literary Partners v. Time, Inc. (Del. July 24, 1989) (available on LEXIS and WESTLAW).

The directors' duty in the context of a noncoercive tender offer is to be contrasted with their duty to maximize current share value in the Revlon-mode and their prerogative to forsake immediate value maximization in ordinary business matters. See id. at 93,277-78.

241 For a broad analysis of these issues, see generally Lipton, supra note 36. 
tender offeror. ${ }^{242}$ Since the noncoercive tender offer in this Comment contains neither of these conditions, one might expect that the Delaware courts would impose this duty upon the target directors. ${ }^{243}$ In any event, the directors of a corporation have a duty to act in the best interests of the shareholders. In the noncoercive tender offer context, this duty would require the target's directors to attempt to negotiate with the tender offeror for the target's "full" value. ${ }^{244}$

\section{ConClusion}

The widespread use of antitakeover devices to obstruct noncoercive tender offers has created a dilemma for Delaware's courts. ${ }^{245}$ The target directors' inherent conflict of interest in corporate control contests presents a potential for abuse that is greater than that contemplated by the business judgment rule but less than that of the intrinsic fairness test. ${ }^{246}$ Since the judicial review of directors' actions should reflect the potential for directorial abuse, an intermediate standard is required to properly evaluate the use of antitakeover devices. ${ }^{247}$

The Delaware Supreme Court recognized this problem in Unocal Corp. v. Mesa Petroleum Co. and attempted to formulate an intermediate standard of review. ${ }^{248}$ The present version of the Unocal test has proved unsatisfactory because it contains ambiguous language that has led to its inconsistent application. ${ }^{249}$ The greatest failing of the Unocal test, however, lies in its attempt to create an intermediate

242 See TW Servs., [Current] Fed. Sec. L. Rep. (CCH) at 92,178-80.

243 See supra note 28 and accompanying text. In fact, Chancellor Allen has even suggested that the target directors' duty of due care may require negotiations with the tender offeror to find out the highest price it will pay. See City Capital Assocs. v. Interco, Inc., 551 A.2d 787, 803 n.21 (Del. Ch. 1988) (Allen, C.J.), appeal dismissed, 556 A.2d 1070 (Del. 1988); see also In re Fort Howard Corp. Shareholders Litig., No. 9991, slip op. at 3 (Del. Ch. Aug. 8, 1988) (Allen, C.J.) (noting that duty of due care in corporate control contests "places a special burden upon the directors to make sure that they have a basis for an informed view" and that the Special Committee there purportedly intended to make "an effective check of the market"). Vice Chancellor Jacobs has also intimated that the duty of due care may require the directors to inquire into the possibility that the tender offeror may increase its tender price. See Robert M. Bass Group v. Evans, 552 A.2d 1227, 1240-41 (Del. Ch.) (Jacobs, J.), appeal dismissed sub nom. MacMillan, Inc. v. Robert M. Bass Group, 548 A.2d 498 (Del. 1988).

244 See supra notes 62-64 and accompanying text.

245 See supra notes 85-98 and accompanying text.

246 See supra notes 90, 92-93 and accompanying text.

247 See supra notes $94-98$ and accompanying text.

248 See supra note 100 and accompanying text.

249 See supra notes 111-70 and accompanying text. 
level of review that involves an evaluation of the antitakeover device's reasonableness. This determination necessarily requires a court to judge the merits of the directors' decision. ${ }^{250}$ This form of judicial review effectively substitutes the court's judgment for that of the directors by applying a standard of review akin to the intrinsic fairness test. ${ }^{251}$ This is particularly true in the noncoercive tender offer context, in which the business decision involves the comparison of two quantities: the tender price and the target's "full" value. ${ }^{252}$ Either one value or the other is greater; there is no middle ground. Many courts have simply avoided this degree of scrutiny and have applied a standard of review equivalent to the business judgment rule. ${ }^{253}$

This Comment has demonstrated that the ambiguous aspects of the Unocal test may be resolved by reference to two underlying principles in the Unocal opinion: that directors must act in the shareholders' best interests, and that courts should engage in an intermediate review of directors' actions in corporate control contests. ${ }^{254}$ This Comment suggests that courts adopt a set of presumptions to guide their determination of an antitakeover device's reasonableness. These presumptions provide an intermediate standard of review because they are more demanding than the business judgment rule, yet they do not require a substantive evaluation of the directors' decision, as does the intrinsic fairness test. ${ }^{255}$ In addition, since these presumptions reflect the economic realities facing the target corporation, they do not impinge upon the directors' ability to pursue an alternative option that would maximize shareholder wealth. ${ }^{256}$ More importantly, this Comment's definition of reasonableness will promote certainty and uniformity through its establishment of a bright-line rule for courts and corporate combatants. This Comment's proposed reformulation of the Unocal test meets the Delaware Supreme Court's call for a truly intermediate standard of review and fulfills the need for uniformity and predictability in antitakeover law.

\footnotetext{
250 See supra note 150 and accompanying text; supra text preceding note 151 .

251 See supra notes 213-14 and accompanying text.

252 See supra text accompanying note 151.

253 See supra notes $160-63 \&$ 215-17 and accompanying text.

254 See supra notes $172-202 \& 211-38$ and accompanying text.

255 See supra text accompanying notes 200-02.

256 See supra notes $230-36$ and accompanying text.
} 